\title{
12. Uzaktan eğitimle Türkçenin yabancı dil olarak öğretimi sürecinde temel becerilerin gerçekleştirilebilme durumunun öğretici görüşleri üzerinden değerlendirilmesi
}

Yalçin YURDAKUL1

Gül Banu DUMAN²

\begin{abstract}
APA: Yurdakul, Y.; Duman, G. B. (2021). Uzaktan eğitimle Türkçenin yabancı dil olarak öğretimi sürecinde temel becerilerin gerçekleştirilebilme durumunun öğretici görüşleri üzerinden değerlendirilmesi. RumeliDE Dil ve Edebiyat Araşttrmalar Dergisi, (23), 167-186. DOI: 10.29000/rumelide.953696.
\end{abstract}

\section{$\ddot{O} \mathbf{z}$}

2020 yılının Mart ayında ortaya çıkan Covid-19 pandemisi, geleneksel yaşam biçimini büyük ölçüde değiştirmiştir. Sosyal mesafeyi korumanın yaşamsal boyutu nedeniyle eğitim-öğretim faaliyetleri eş zamanlı ya da eş zamansız uzaktan eğitim modelleriyle yürütülmeye başlanmıştır. Bu doğrultuda “Türkçenin yabancı dil olarak öğretimi” faaliyetleri de yurt içinde ve yurt dışında zorunlu olarak eş zamanlı uzaktan eğitim modeliyle sürdürülmektedir. Bu çalışmada Türkiye'de uzaktan eğitimin Türkçenin yabancı dil olarak öğretimi alanında uygulanması süreci üzerinde durulmuş, sürece kurumsal ve bireysel hazır oluş olgusu tartışılmıştır. Alan uygulamalarının kalitesini etkileyen sorunlar üzerinde tespitler yapılmış, sürecin sağlıklı yürütülebilmesi için öneriler sunulmuştur. Yurt içinde ve yurt dışında Türkçenin yabancı dil olarak öğretimi alanında görevlendirilmiş alan uzmanlarının görüşlerine ulaşılmış; alan uzmanı olan öğreticilerin görüşleri üzerinden "dinlemeanlama”, "okuma-anlama", "konuşma” ve "yazma” becerilerinin gerçekleştirilebilme durumu nitel durum çalışması olarak ele alınmıştır. Alan uzmanlarının görüşleri öğreticinin "eğitimi” ve “mesleki tecrübesi” değişkenleri bakımından irdelenmiştir.

Anahtar kelimeler: Uzaktan eğitim, Türkçenin yabancı dil olarak öğretimi, temel beceriler, eğitim seviyesi, mesleki tecrübe

\section{Evaluation of Basic Skills' achievements in the Process of Teaching Turkish Language to Foreigners through Online (Distance) Education on Educators' Perspective}

\begin{abstract}
Covid 19 pandemic which occured on March 2020, changed the traditional lifestyle in a visible way. In order to maintain the social distance, educational activities have been executed via television or online platforms synchronous/asynchronous. In this matter, it has been focused on using distant education on foreigners' Turkish education and it has been discussed the subject of being ready as corporate and individual. Determinations have been done on the problems which effects the field applications, suggestions have been offered in order to conduct the period in a efficient way. In the
\end{abstract}

Okutman, Makhambet Utemisov West Kazakhstan Universitesi, Kazakh Filologia (Ural, Kazakistan) yalcinyurdakul@gmail.com, ORCID ID: oooo-0003-2614-9076. [Araştırma makalesi, Makale kaylt tarihi: 06.05.2021kabul tarihi: 20.06.2021; DOI: 10.29000/rumelide.953696], ETIK: Zonguldak Bülent Ecevit Üniversitesi İnsan Araștırmaları Etik Kurulu, 29.01.2021, Protokol: 31.

Doç. Dr., Zonguldak Bülent Ecevit Üniversitesi, Fen Edebiyat Fakültesi, Türk Dili ve Edebiyatı Bölümü (Zonguldak, Türkiye), gulbanuduman@gmail.com, ORCID ID: 00oo-00o2-6593-3587.

Adres | Address

RumeliDE Dil ve Edebiyat Araştırmaları Dergisi $\quad$ RumeliDE Journal of Language and Literature Studies Osmanağa Mahallesi, Mürver Çiçeği Sokak, No:14/8 Osmanağa Mahallesi, Mürver Çiçeği Sokak, No:14/8

Kadıköy - İSTANBUL / TÜRKIYE 34714 Kadıköy - ISTANBUL / TURKEY 34714 e-posta: editor@rumelide.com

e-mail: editor@rumelide.com,

tel: +90 505 7958124, +90 216773 o 616 phone: +90 505 7958124, +90 2167730616 
Evaluation of Basic Skills' achievements in the Process of Teaching Turkish Language to Foreigners through Online (Distance) Education on Educators' Perspective / Y. Yurdakul; G. B. Duman (pp. 153-186)

\begin{abstract}
study, perspectives of the trainers who are in charge of teaching Turkish as a foreign language in country and/or abroad are being evaluated. In the study, "listening- understanding", "readingunderstanding", "speaking" and "writing" skills' achivements are considered as qualitative research of condition through the perspective of educators who are experts of fields. Perspectives of filed's experts are considered by taking the educator's 'education' and 'professional experience' parameters as a base.
\end{abstract}

Keywords: Online education, Teacing Turkish as a foreign Language, base/essential skills, degree of education, Professional experience

\title{
Giriş
}

Küresel felaket senaryoları ve beklentileri 2020 yılının hemen başında somut bir gerçek olarak Covid19 pandemisi olgusu ile ortaya çıtı. Pandemi, kargaşaya; kargaşa ise yeni bir düzene evrildi. "Kaos kuramına göre dünyanın herhangi bir bölgesinde meydana gelen bir olay başka bir olayın tetikleyicisi olabilir. Bu bağlamda düzen düzensizliği yaratır ve tetikleyici olayın sonuçları sistemin tüm bileşenlerini etkileyebilir." (Lorenz'den [1972] akt. Bozkurt, 2020) Dünyanın neredeyse her noktasını etkileyen pandemi; ekonomik işleyişi, beşerî ilişkileri, kültürel dinamikleri, üretim ve eğitim-öğretim sürecini az ya da çok değiştirmiş durumdadır. Tüm bu alanlarda alışılmışın dışına çıkılmasını gerektiren pandemi süreci, yaşam biçiminin geleneksel olan tüm paydaşlarında yeniden şekillenmeyi zorunlu kılmıştır. İnsanlar arasında fiziki temas gerektiren tıp, spor ve çeşitli hizmet alanlarında nispeten sınırlı bir davranış değişikliğine gidilmiştir. Ancak fiziki temas gerektirmeyen alanlarda geleneksel normların dışına çıkılmış, çözümler çok hızlı biçimde hayata geçirilmiştir. Ekonomik faaliyetler mümkün olduğu ölçüde çevrim içi ağ üzerinden yürütülmüş; birçok kamu hizmetinde ve iş dünyasında dönüşümlü çalışma ve esnek çalışma modelleri yanında, çalışanların kurum binalarına gitmeden yükümlülüklerini yerine getirebileceği evden çalışma gibi sistemler işletilmiştir.

Örgün ve yaygın eğitim faaliyetleri ise mekân yanında yöntem değişikliğine de gitmiştir. Coğrafi uzaklık, sosyal dengesizlik ve bireysel sorunlar; uzaktan eğitimin toplumun bütün kesimlerine yönelik olarak yaygınlaştırılmasının üç temel nedeni olarak gösterilmektedir (Odabaş, 2003). Pandemi döneminde klâsik öğrenme ve öğretme etkinlikleri; mekân, sosyal eşitsizlik ve bireylerin içine itildikleri sorunlar sebebi ile yürütülemez duruma gelmiştir. "Maske, mesafe, temizlik" tedbirleri gereği yüz yüze eğitim-öğretimin olanaksız hâle gelmesiyle eğitim faaliyetleri çevrim içi olarak uzaktan eğitim yoluyla gerçekleştirilmeye başlanmıştır.

"Uzaktan eğitim; geleneksel öğrenme-öğretme yöntemlerinin sınırlılıkları nedeniyle sinıf içi etkinliklerini yürütme olanağının bulunmadığı durumlarda, eğitim etkinliklerini planlayıcılar ile öğrenciler arası, iletişim ve etkileşimin özel olarak hazırlanmış öğretim üniteleri ve çeşitli ortamlar yoluyla belirli bir merkezden bir öğretme yöntemi” (Kaya vd. 2004, s.166) olarak tanımlanabilir. Uzaktan eğitimde "öğretici" ve "öğrenenin iletişim süreci” bakımından iki temel model vardır: Öğrenciye sunulacak yazılı, görsel ve işitsel materyallerin web üzerinde hazır hâle getirildiği, öğrencinin zaman ve mekândan bağımsız olarak bu web ortamından yararlanabildiği tek yönlü iletişim formu; "eş zamansız" (asenkron) modeldir. Öğretici ve öğrenenin programlanmış zaman dilimleri içerisinde sanal web platformlarında çift yönlü iletişime geçebildikleri, dosya paylaşımı yapmaya imkân tanıyan ve böylece anlık dönütler ile sağlıklı öğrenme bağlamının kurulabildiği form; "eş zamanlı" (senkron) modeldir.

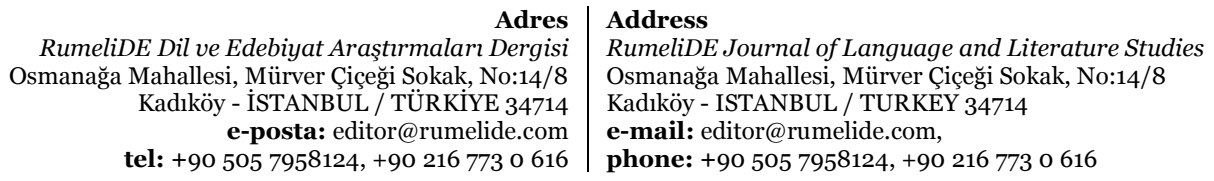




\section{Türkiye'de uzaktan eğitim sürecinin tarihçesi:}

Türkiye'deki uzaktan eğitim sürecine bakmak mevcut durumun anlaşılmasını kolaylaştıracaktır. Uzaktan eğitim uygulamalarının tarihi, Cumhuriyetin kuruluş yllarına dek gider (Bozkurt, 2017). Bu dönemde basılı materyaller ile başlayan, ses ve görüntü temelli görsel araçlarla devam eden; ancak tek yönlü iletişim sunabilen uzaktan eğitim uygulamalarıyla Millî Eğitim Bakanlığı, ODTÜ ve Anadolu Üniversitelerinin projeleri özelinde 200o'li yıllara kadar gelinmiştir. Bu yıllarda teknoloji kullanımının eğitim alanında giderek yaygınlaşmasıyla çevrimiçi eğitim modellerine geçiş süreci hızlanmıştır. (Kılıç vd., 2016). Millî Eğitim Bakanlığının 2012 yllında uygulamaya koyduğu Eğitim Bilişim Ağı (EBA) projesi, lisans öncesi her tür eğitim seviyesinde sınırlı etkileşimli nitelikte başarılı bir uzaktan eğitim uygulamasıdır. Üniversite seviyesinde ise uzaktan eğitim uygulama ve araştırma merkezleri (UZEM) aracılığı ile yaygınlaşan uzaktan eğitim uygulamaları, genel olarak alan uzmanlı̆̆ gerektirmeyen dersleri içeren bir formatta yürütülmektedir. 2020 yllı verilerine göre 176 üniversitenin 117'sinde "zorunlu ortak dersler"in uzaktan eğitim uygulamasıyla yürütüldüğü görülmektedir. (Eroğlu ve Kalaycı, 2020). Ancak gerek üniversite öncesi gerekse üniversite seviyesindeki uzaktan eğitim uygulamaları ekseriyetle tek yönlü, sınırl etkileşimli niteliktedir. Yazı, ses ve video dosyalarının paylaşımı ile bilgilendirme yapmak üzerine kurgulanmış bu sistemler öğrenciyi yeterince merkeze alabilen "eş zamanlı" uygulamalar değildir.

Türkiye'de kurumsal bazda uzaktan eğitimin “Türkçenin yabancı dil olarak öğretimi” sahasında kullanılmaya başlanması, 2007 yılında Anadolu Üniversitesince tasarlanan "Uzaktan Türkçe Öğretim Programı”na dayanır. Bu Türkçe Sertifika Programı’nda onar kişilik öğrenci gruplarından oluşturulan sanal sınıflarda haftada iki gün, birer saat ses, görüntü ve yazılı iletişim kullanılarak konuşma ve yazma becerilerine yönelik eş zamanlı danışmanlık hizmeti verilebilmekteydi (Mutlu vd., 2014). Ancak Anadolu Üniversitesinin 2018 yılında uygulamaya koyduğu güncel "Ana-dil” programı her ne kadar içerik bakımından çok zenginleşmişse de bütünüyle "eş zamansız" metodu benimsemiş durumdadır.

Eş zamanlı eğitim uygulamalarının Türkçenin yabancı dil olarak öğretimi alanında kullanıldığı ilk örnekten günümüze iletişim teknolojilerinde olağanüstü gelişmeler yaşanmaktadır. Teknolojinin hayatı kolaylaştıran bir yönü olarak mobil cihazların eğitimde yaygın biçimde kullanılması neticesinde e-öğrenme ve m-öğrenme (tanımlar için bk. Balaban, 2012) yöntemleri etkinliğini artırmıştır. Eğitimin ticari bir meta olma yönünün ağır bastığı alanlarda e-öğrenme ve m-öğrenme tabanlı öğretim uygulamalarının hızla yaygınlaştı̆̆ı; ancak örgün eğitim boyutunda uyum sürecinin yavaş işlediği görülmektedir.

Türkiye’de kamu kurumları ve özel kurumlar bünyesindeki dil öğretim merkezleri, web tabanlı eş zamansız modeller ile yabancı dil olarak Türkçenin uzaktan öğretimi alanında faaliyet göstermektedirler:

T.C. Başbakanlık Yurtdışı Türkler ve Akraba Toplulukları Başkanlığı "3 dakikada Türkçe” (https://www.youtube.com/channel/UCWfJXGs64xNZVjoSp_YimZQ),

Anadolu Üniversitesi (https://acik.anadolu.edu.tr/)

Ankara Üniversitesi TÖMER (www.distance-turkish.com),

Yaşar Üniversitesi Açık ve Uzaktan Öğrenme Merkezi (https://turkish.yasar.edu.tr/),

\begin{tabular}{|c|c|}
\hline & \\
\hline & dies \\
\hline & okak, No:14/8 \\
\hline $\begin{array}{r}\text { Kadıköy - İSTANBUL / TÜRKIYYE } 34714 \\
\text { e-posta: editor@rumelide.com } \\
\text { tel: +90 505 7958124, +90 } 2167730616\end{array}$ & $\begin{array}{l}\text { Kadıköy - ISTANBUL / TURKEY } 34714 \\
\text { e-mail: editor@ rumelide.com, } \\
\text { phone: + 90 505 7958124, +90 } 216773 \text { o } 616\end{array}$ \\
\hline
\end{tabular}


Evaluation of Basic Skills' achievements in the Process of Teaching Turkish Language to Foreigners through Online (Distance) Education on Educators' Perspective / Y. Yurdakul; G. B. Duman (pp. 153-186)

Yunus Emre Enstitüsü (https://turkce.yee.org.tr/tr), bu alanda açlk ders materyalleri sunan eöğrenme ortamlardan bazılarıdır.

Millî Eğitim Bakanlığı tarafından Türkiye'de eğitim gören göçmen çocukların Türkçe öğrenmesine katkıda bulunmak için hazırladığı "Bil Bakalım 1" ve "Bil Bakalım 2" m-öğrenme uygulamaları yalnızca temel kelimeleri içeren sözlükler olarak bir ihtiyacı karşılayan mobil uygulamalardır. Bugün itibariyle kazandırılması gereken temel becerilere yönelik e-öğrenme ve m-öğrenme bağlamında henüz yeterli ders içerik üretiminin olmadığı görülmektedir. Bu durum UETYÖ sürecinde öğreticilerin bireysel çözümler bulmalarını gerektirmekte, bu da sürecin bütününde standart yakalanamamasına yol açan sorunlu bir alan olarak görülmektedir.

İlgili alanın standartlarının ve tecrübelerinin aktarıldığı, mesleki yeterliliğin kazanıldığı temel akademik süreç, lisan eğitimidir. Öğreticilerin lisans eğitimlerinde Türkçenin yabancı dil olarak öğretimi alanı için temel becerilere sahip olmaları yanında e-öğrenme ve m- öğrenme materyalleri hazırlamaya yönelik kazanımları da edinmeleri beklenebilir. Mevcut duruma bakıldığında ise yabancı dil olarak Türkçe öğretimi alanında yükseköğretim lisans eğitimiyle mesleki bakımdan alan uzmanı yetiştirilmiyor oluşu diğer bir sorunlu husus olarak ortaya çıkmaktadır. Yurt içi ve yurt dışında görev yapan öğreticiler, anadili eğitimi alan yakın lisans disiplinlerinden oluşturulmaktadır. Ancak Türkçenin yabancı dil olarak öğretimi ile anadili olarak Türkçe öğretimi farklı disiplinlerdir. Büyükaslan'ın (2007) ifade ettiği üzere Avrupa'da bu alanda lisans bölümleri kurulmuştur. Bu bölümlerde bilişim teknolojilerinin dil öğretimi alanında kullanımı öğretildiği gibi yurt dışı staj tecrübesi de zorunlu tutulmaktadır.

Türkiye'de öğreticilerin lisans düzeyinde yetiştirilmesine yönelik ilk çalışma, "Yabancllara Türkçe Öğretimi” dersinin 1992 yılında Gazi Üniversitesinde ders programına eklenmesidir (Özbay ve Bahar, 2016). Bugün itibariyle alan uzmanı yetiştirmeye yönelik lisansüstü programlar yapılıyor olsa da bunların akademik kariyer çalışmalarının ötesine geçemediği, kapsayıcı olamadığı söylenebilir. Bu hususun bir problem olarak ele alınması elbette ki öğreticilerin yetersizliği olarak değerlendirilmemelidir. Özbay ve Bahar'ın (2016) ifadesi ile her uzmanlık alanında olduğu gibi Türkçenin yabancı dil olarak öğretiminde yetkinlik, "temel uzmanlık yeterlilikleri” olarak adlandırılan bilgi ve becerilerin kazanıldığı lisans eğitimine bağlıdır.

Pandemi sürecinde yabancı dil olarak Türkçe öğretimi, değişen normlarla birlikte bütünüyle eş zamanlı uzaktan eğitime evrilmiştir. Yukarıda ifade edilen hususlara ilave olarak bu alanda eş zamanlı uzaktan eğitime yönelik temel ilkelerin belirlenmediği, alan çerçevesinin oluşturulmadı $\breve{g}$, kurumsal bir eğitim programının hazırlanmadığı, kurumların ve öğreticilerin bu sürece "materyal" ve "alan lisans eğitimi” hususlarında büyük oranda hazırlıksız yakalandığı söylenebilir. Oysa, Balaban'a göre (2012) uzaktan eğitime kurumsal olarak hazır olunması bu eğitim sisteminin başarısında ilk koşuldur.

Yabancı dil olarak Türkçe öğretiminin tümüyle çevrim içi yürütüldüğü bu süreç hem öğreticiler hem de öğrenciler için yeni bir tecrübe olmuştur. Yüz yüze eğitimde elektronik ya da basılı materyaller üzerinden, doğal dil ortamında ve çoğunlukla 12-24 ders saatinde kazandırılmaya çalışılan dil becerileri; eş zamanlı uzaktan eğitimin kısıtlayıcı boyutları içerisinde gerçekleştirilmeye çalışılmaktadır. Öğreticiler, doğal dil ortamının bulunmadı bir boyutta, materyal yoksunluğu içinde ve daha az zaman zarfında aynı becerileri kazandırmak için mücadele etmek zorunda kalmaktadır. Öğreticilerin bu kısıtllılılar içinde "dinleme-anlama, okuma-anlama, konuşma, yazma" becerileri yönüyle öğrencileri istendik düzeye getirebilmeleri için kişisel birikim ve yeteneklerini ön plana

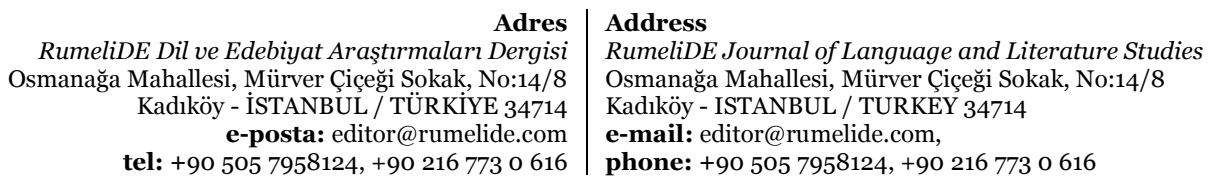


çıkarmaları gerektiği görülmüş; öğreticinin “eğitim seviyesi” ve mesleki tecrübesi” temel değişkenler olarak ortaya çlkmıştır.

\section{2. Çalışmanın amacı ve önemi:}

“Türkçenin yabancı dil olarak öğretimi” alanında faaliyet gösteren kurum ve öğreticilerin temel hedefleri "dinleme-anlama, okuma-anlama, konuşma, yazma” becerileri yönüyle öğrencileri istendik düzeye getirebilmektir. Covid-19 pandemi süreci “Türkçenin yabancı dil olarak öğretimi”nde uzaktan eğitimi zorunlu kılmıştır. Bu süreçte mevcut deneyimlerin ışığında dört temel becerinin gerçekleştirilme durumunu, öğreticilerin görüşlerinden hareketle tespit etmek bu çalışmanın temel amacıdır. Üretme ve uygulama yönüyle asıl unsur olduğu görülen öğreticilerin görüşlerinden hareketle ortaya çıan bu çalışmanın sürece katkı sunacağı düşünülmektedir.

Çalışmada dört temel dil becerisine ait altı probleme cevap aranmıştır. Ayrıca her temel problem öğreticinin “eğitim seviyesi” ve "mesleki tecrübesi” değişkenlerine göre iki alt problemle genişletilmiştir.

1. Uzaktan eğitimle Türkçenin yabancı dil olarak öğretimi sürecinde "dinleme-anlama" becerisinin yeterince geliştirilebildiğini düşünüyor musunuz?

2. Uzaktan eğitimle Türkçenin yabancı dil olarak öğretimi sürecinde "okuma-anlama" becerisinin yeterince geliştirilebildiğini düşünüyor musunuz?

3. Uzaktan eğitimle Türkçenin yabancı dil olarak öğretimi sürecinde "konuşma" becerisinin yeterince geliştirilebildiğini düşünüyor musunuz?

4. Uzaktan eğitimle Türkçenin yabancı dil olarak öğretimi sürecinde "yazma” becerisinin yeterince geliştirilebildiğini düşünüyor musunuz?

5. Uzaktan eğitimle Türkçenin yabancı dil olarak öğretiminin en başarılı olduğu beceri hangisidir?

6. Uzaktan eğitimle Türkçenin yabancı dil olarak öğretiminin en başarısız olduğu beceri hangisidir?

Uzaktan eğitimle Türkçenin yabancı dil olarak öğretimi (UETYÖ) sürecini, öğreticilerin deneyimleri üzerinden değerlendirmeye yönelik çalışmaların henüz yeterli seviyede olmadığı görülmektedir. Süreç, tüm yönleri ve farklı bakış açıları ile değerlendirilmeye muhtaç durumdadır. Bu çalışma, dünyanın birçok ülkesinde ve yurt içinde çalışan alan uzmanlarının görüşlerini içermesi yönüyle kapsayıcı bir çalışma olmuştur.

UETYÖ sürecinde ortaya çıkan engelleyici hususların, öğretici tutumlarında görülen farklılı̆̆ın, kazanımların aktarılabilmesi sürecindeki aksayan yönlerin tespit edilmesinde çalışmanın ortaya koyduğu veriler sürece katkı sunacaktır. Elde edilen verilerin öğretim programları, içerik üretimi, öğreticilerin eğitimi çalışmalarına da ışık tutacağı; sürecin karar vericilerinine yol göstereceği düşünülmektedir.

\begin{tabular}{r|l} 
Adres & Address \\
RumeliDE Dil ve Edebiyat Araşțrmaları Dergisi & RumeliDE Journal of Language and Literature Studies \\
Osmanağa Mahallesi, Mürver Çiçeği Sokak, No:14/8 & Osmanağa Mahallesi, Mürver Çiçeği Sokak, No:14/8 \\
Kadıöy - İSTANBUL / TÜRKIYY 34714 & Kadıköy - ISTANBUL / TURKEY 34714 \\
e-posta: editor@rumelide.com & e-mail: editor@rumelide.com, \\
tel: +90 505 7958124, +90 216773 o 616 & phone: +90 505 7958124, +90 216773 o 616
\end{tabular}


Evaluation of Basic Skills' achievements in the Process of Teaching Turkish Language to Foreigners through Online (Distance) Education on Educators' Perspective / Y. Yurdakul; G. B. Duman (pp. 153-186)

\section{3. Çalışma evreni ve sınırı:}

$\mathrm{Bu}$ çalışma Covid-19 pandemisi ile zorunluluk hâline dönüşen web tabanlı uzaktan öğrenme metodunun, UETYÖ sürecinde temel becerilerin gerçekleştirilebilmesi üzerindeki etkilerinin öğreticilerin görüşleri üzerinden tespit edilmesi ile sınırlandırılmıştır. Öğretici, "sanal sınıf uygulaması bulunan eşzamanlı uzaktan dil öğretim programlarında dersi anlatan, öğrenci ile yüz yüze iletişim kuran, soruları cevaplayan dil uzmanlarıdır. Sanal sinıf uygulamaları olan web tabanlı uzaktan dil öğretim programlarında, öğreticilik yeni bir meslek olarak ortaya çıkmıştır.” (Pilancı, 2015).

MEB Yükseköğretim ve Yurt Dışı Eğitim Genel Müdürlüğünce okutman görevlendirilen yurt dışındaki üniversiteler, yurt içinde kamu kurumları ve özel kurumlar, Maarif Vakfı, Yunus Emre Enstitüsü ile Kırgızistan-Türkiye Manas Üniversitesi ve Ahmet Yesevî Üniversitesi bünyesindeki TÖMER'lerde UETYÖ faaliyeti sürdüren alan uzmanları bu çalışmada görüşleri alınan “öğreticiler”dir.

\section{Verilerin toplanması ve analizi:}

Araştırma, "nitel durum çalışması" deseniyle ve "online anket veri toplama" tekniği ile tasarlanmıştır. Bu tercihin iki temel nedeni, "pandemi sürecinin getirdiği kısıtlllıklar" ile "araştırma kapsamının yurt içi ve yurt dışında görev yapan çok sayıda alan uzmanına ulaşmayı gerektirmesi”dir.

Ankette uzaktan öğretimin yabancı dil olarak Türkçe öğretimi süreci üzerindeki etkilerini tespit etmeye yönelik çoktan seçmeli ve açık uçlu sorulara yer verilmiştir. Hazırlanan taslak form; Türkçenin yabancı dil olarak öğretimi alanında alanyazına katkı sunmuş uzmanların görüşlerine sunulmuş, test grubu üzerinde uygulanmış ve nihai hâline getirilmiştir.

Verilerin toplanması safhasında Google Form'da oluşturulan anketten yararlanılmıştır. MEB Yükseköğretim ve Yurt Dışı Eğitim Genel Müdürlüğünce oluşturulan hizmet içi WhatsApp grupları yoluyla çeşitli ülkelerde Türkçenin yabancı dil olarak öğretimi için görevlendirilmiş okutmanlara/öğretmenlere ulaşılmıştır. Yurt içi ve yurt dışında yukarıda isimleri zikredilen diğer kurumların bünyesinde faaliyet gösteren öğreticiler sürece dâhil edilmiştir. Bu durum çalışmanın güvenilirliğini ve geçerliliğini artırmaktadır. Kişisel bilgilerin toplanmadığı ankete web üzerinden 89 alan uzmanı katılmış ve görüş bildirmiştir.

Elde edilen verilere, olgular arasındaki bağıntıları ortaya çıkarılabilmesi yönü (Yıldırım, Şimşek, 2018) ile "içerik analizi" uygulanmıştır. Benzer cevaplar gruplandırılmış, ortaya çıkan verilerin gösterimi için istatistiksel teknikler, sayısal dağılımlar, yüzdelik dilimler kullanılmıştır. Yüzdelik dilim verilirken aşağıya yuvarlama yapıldığından toplamda \%o.2 sapma görülebilmektedir.

Araştırma için Zonguldak Bülent Ecevit Üniversitesi İnsan Araştırmaları Etik Kurulundan 26.01.2021 tarih ve 31 sayılı etik kurul kararı alınmıştır.

\section{Bulgular:}

Türkçenin yabancı dil olarak öğretiminin temel gayesi, dört temel dil becerisini belirlenen hedefler ölçeğinde gerçekleştirebilmektir. Dilin doğal edinimi sürecinin "dinleme-anlama” becerisi ile başladığı daha sonra "konuşma", "okuma-anlama" ve "yazma" becerilerinin kazanılması ile gerçekleştiği kabul edilir (Memiş ve Erdem, 2013, s.303). Bu bölümde, temel becerilerin gerçekleştirilme durumu "iki alt

\footnotetext{
Adres $\mid$ Address

RumeliDE Dil ve Edebiyat Araşttrmaları Dergisi $\quad$ RumeliDE Journal of Language and Literature Studies Osmanağa Mahallesi, Mürver Çiçeği Sokak, No:14/8 Osmanağa Mahallesi, Mürver Çiçeği Sokak, No:14/8 Kadıköy - ISTANBUL / TÜRKIYE 34714 Kadıköy - ISTANBUL / TURKEY 34714 e-posta: editor@rumelide.com e-mail: editor@rumelide.com, tel: +90 505 7958124, +90 2167730616 phone: +90 505 7958124, +90 2167730616
} 
değişken" hâlinde problemleştirilmiştir. Değerlendirmenin değişkenleri öğreticilerin "mesleki tecrübesi" ve "eğitim seviyesi"dir.

Öğreticiler; “1-5 yıl arası” (A grubu), "6-10 yll arası" (B grubu), “10 yıl ve üzeri” (C grubu) "mesleki tecrübe”ye sahip oluşları bakımından gruplandırılmıştır. Yurt içi ve yurt dışında Türkçenin yabancı dil olarak öğretimi alanında hizmet veren ve görüş bildiren öğreticiler içerisinde B grubu öğreticilerin oranı \%19.1, C grubu öğreticilerin oranı \%19.1 iken 1-5 yll tecrübe sahibi A grubu öğreticilerin oranı $\% 61.7$ seviyesindedir.

Çalışmada öğreticiler; “eğitim seviyesi” değişkenine göre "lisans” (L grubu), “yüksek lisans” (YL grubu) ve "doktora” (DR grubu) olarak gruplandırılmıştır. Görüş bildiren öğreticiler içerisinde L grubu, \%8.9, YL grubu, \%55, DR grubu \%35.9'luk bir ağırlı̆̆ı oluşturmaktadır. Çalışmada görüş bildiren öğreticilerin \%90.9 oranında lisansüstü eğitime sahip oldukları görülmektedir.

Ayrıca "Araştırmaya katılan öğreticilerin \%60’ı (53 kişi) küresel salgından önce uzaktan öğretim deneyimine sahip olmadığını belirtmiştir.” (Duman ve Yurdakul, 2021, s.434).

\section{Problem: Uzaktan eğitimle Türkçenin yabancı dil olarak öğretimi sürecinde "dinleme- anlama" becerisinin yeterince geliştirilebildiğini düşünüyor musunuz?}

"Dinleme-anlama", dilin tarihsel süreç içerisinde ortaya çıan birikiminin dinleyen tarafından edinildiği bir süreçtir. Diğer beceriler hiç ortaya çımmasa dahi tek taraflı olarak içinde bulunulan dil ortamına uyum sağlayabilmenin ilk basamağı, "dinleme"dir. Öyle ki yıllarca hiç konuşmayan, içinde yaşadığı toplumla tek taraflı iletişimini "dinleme" becerisi üzerinden gerçekleştiren insanlar görülebilmektedir. Ancak doğal konuşma ortamında iletişimi sağlayan iki ana beceriden biri olması sebebiyle dinleme becerisi, dil öğretiminde geliştirilmesi gereken en temel beceridir.

Öğrencinin somut bir eylemde bulunmayışından hareketle "dinleme" becerisinin, diğer becerilere kıyasla pasif bir öğrenme süreci olduğu söylenebilir. Ancak yapılan çalışmalar, dinlemenin aktif bir edinim olduğunu ve diğer becerilerin gelişimini de etkilediğini göstermektedir (Vandergrift ve Goh, 2012, s.304). "Dinlemek" eylemi kendi içerisinde duyduğunu kavrama ve muhakeme edebilme becerisi olarak "duymak" eyleminden farklılaşır. "Dinleme, konuşmada ileri sürülen düşünceleri anlamak, yorumlamak, değerlendirmek, organize etmek, aralarındaki ilişkileri saptamak ve belleğimizde saklamaya değer bulduklarımızı seçip ayırmak demektir.” (Taşer, 2012, s. 206). Bu farklılık “dinleme”yi bir "beceri” kılmaktadır ve bu yönüyle geliştirilmesi elzemdir.

Dinleme becerisinin yabancı dil olarak Türkçenin öğretimi alanında "ayrıştırıcı dinleme" açısından önemli bir yanı vardır. Melanlıŏlu (2011, s.72) dilin sesleri ve kişilerin telaffuzları konusunda fonetik farkındalıkları arttırmak yolunda dinleme becerisinin kullanılmakta olduğunu ifade eder. İletişim bağlamı içerisinde mesajın yüklendiği kelimeler alıcının kelime hazinesinde varsa dinleme anlama gerçekleşebilir; ancak alıcı-dinleyici pasif olduğu ve ayrıştırıcı dinleme süreci devam ettiği için "dinleme-anlama becerisinin edinimi, hedef dili yoğun biçimde duymayı gerektirir.

"Uzaktan eğitimle Türkçenin yabancı dil olarak öğretimi sürecinde “dinleme-anlama” becerisinin yeterince geliştirilebildiğini düşünüyor musunuz?” sorusuna yönelik öğretici görüşleri çerçevesinde hazırlanan Şekil 1a ve Şekil 1b’nin verileri ışı̆̆ında, öğreticilerin \%20'sinin "hayır”, \%40'ının "kısmen”, \%40’ının "evet” şeklinde görüş bildirmiştir. "Evet” cevabının \%40’ta kaldığı; uzaktan eğitim sürecinde, "dinleme" basamağının istenen ölçüde gerçekleştirilemediği görülmektedir. Uzaktan eğitim sürecinde 
Evaluation of Basic Skills' achievements in the Process of Teaching Turkish Language to Foreigners through Online (Distance) Education on Educators' Perspective / Y. Yurdakul; G. B. Duman (pp. 153-186)

dinleme becerisine bağlı olarak diğer becerilerin gerçekleştirilebilmesinde sorunlar yaşanmakta olduğu ve ilerleyen dönemde de yaşanabileceği söylenebilir.

Aşağıda açıklanan alt problemler çerçevesinde "dinleme-anlama" becerisinde ortaya çlkan olumsuz algı, pandemi sürecine bağlı olarak işitsel uyarıcıları etkileşimli biçimde alabileceği sosyal ortamın olmayışı ile ilişkilendirilebilir.

1a. Alt Problem: Uzaktan eğitimle Türkçenin yabancı dil olarak öğretimi sürecinde “dinleme-anlama” becerisinin geliştirilebilmesi "öğreticinin mesleki tecrübesine” göre değişkenlik göstermekte midir?

Şekil 1a: Mesleki tecrübe değişkenine göre

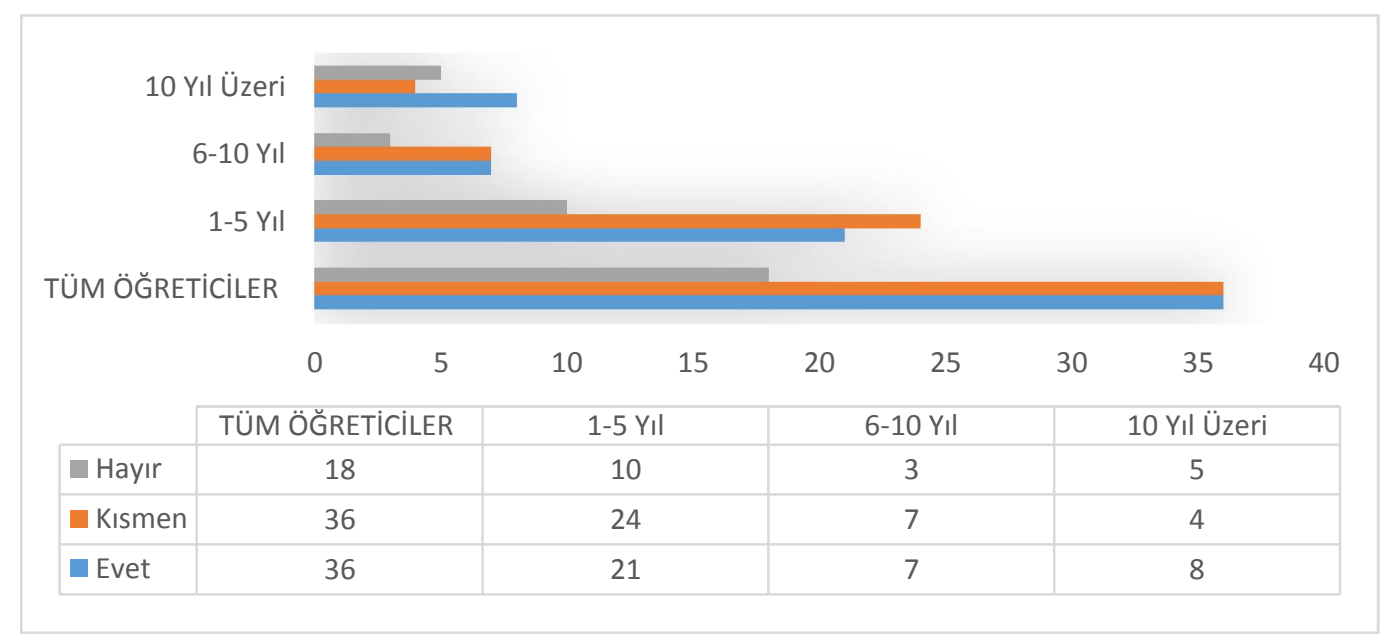

UETYÖ sürecinde "dinleme-anlama" becerisinin geliştirilebilmesi bakımından mesleki tecrübe değişkenine göre öğretici görüşleri değerlendirildiğinde "hayır" ifadesi A grubunda \%18.1, B grubunda \%17.6, C grubunda \%29.4; "kısmen" ifadesi A grubunda \%43.6, B grubunda \%41.1, C grubunda \%23.5; "evet" ifadesi ise A grubunda \%38.1, B grubunda \%41.1, C grubunda \%47 oranındadır. Veriler ışığında mesleki tecrübenin artması ile "dinleme-anlama" becerisinin verilebildiğine işaret eden "evet" ifadeleri de artmaktadır. Ayrıca becerinin gerçekleştirilebilmesi bakımından emin olamamanın da göstergesi olarak "kısmen" cevabı A grubunda \%43.6'ya çıkarken bu oran C grubunda \%23.5'e düşmektedir. Mesleki tecrübenin arttığı C grubunda "dinleme-anlama" becerisinin verilebildiği görüşü belirginleşirken tecrübenin düşmesi ile kararsızlık oranı yükselmektedir. Sonuç olarak mesleki tecrübe değişkeni ile "dinleme-anlama" becerisinin kazandırılması arasında anlamlı bir bağıntı olduğu görülmektedir. 
1b. Alt Problem: Uzaktan eğitimle Türkçenin yabancı dil olarak öğretimi sürecinde “dinleme-anlama” becerisinin geliştirilebilmesi "öğreticinin eğitim seviyesine” göre değişkenlik göstermekte midir?

Şekil 1b: Eğitim seviyesi değişkenine göre

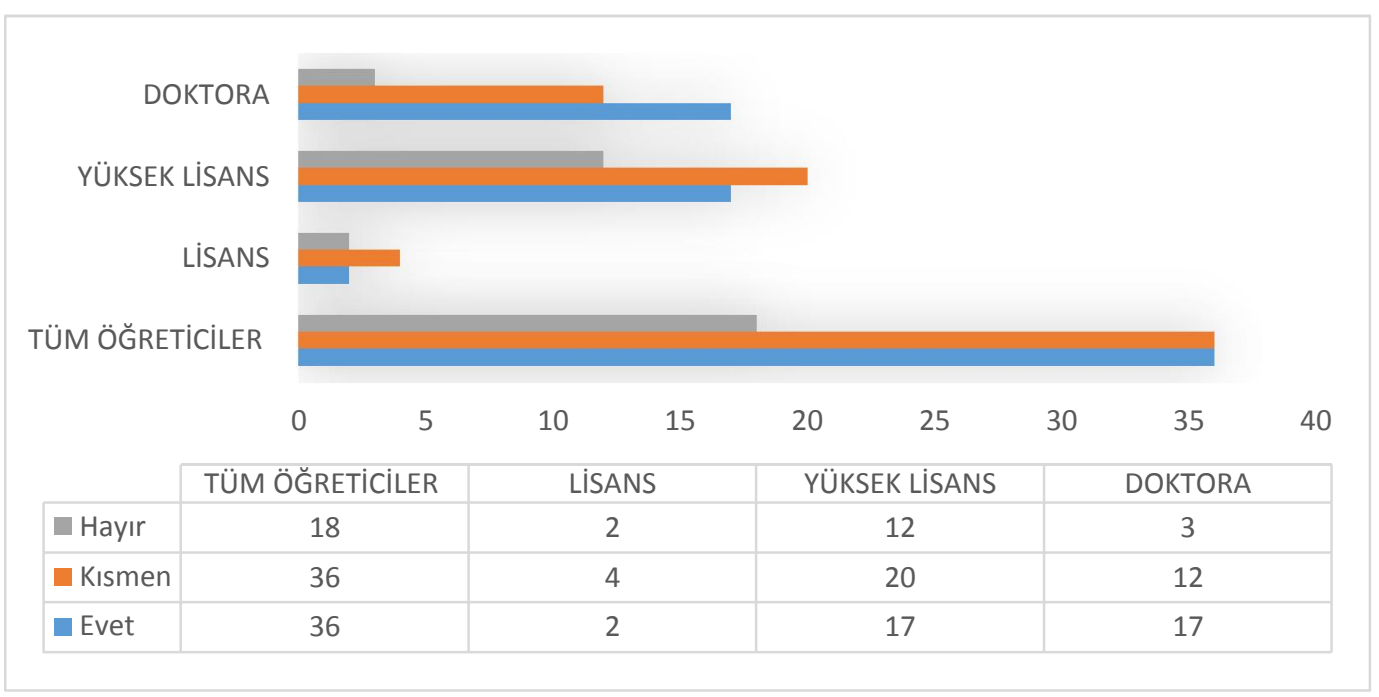

UETYÖ sürecinde "dinleme-anlama" becerisinin geliştirilebilmesi bakımından "eğitim seviyesi değişkeni”ne göre öğretici görüşleri değerlendirildiğinde "hayır” ifadesi L grubunda \%25, YL grubunda \%24.4, DR grubunda \%9.3; "kısmen" ifadesi L grubunda \%50, YL grubunda \%40.8, DR grubunda \%37.5; "evet" ifadesi ise L grubunda \%25, YL grubunda \%34.6, DR grubunda \%53.1 oranindadır. Veriler ışığında "dinleme-anlama" becerisinin gerçekleştirilebildiği algısının, "öğreticinin eğitim seviyesi” ile bağıntılı biçimde arttığı görülmektedir.

\section{Problem: Uzaktan eğitimle Türkçenin yabancı dil olarak öğretimi sürecinde "okuma- anlama" becerisinin yeterince geliştirilebildiğini düşünüyor musunuz?}

UETYÖ sürecinde "okuma-anlama" becerisinin geliştirilebilmesine yönelik görüş bildiren öğreticilerin \%13.4'ü "hayır", \%39.3'ü "kısmen", \%47.1'i "evet” olarak dönütte bulunmuştur. Veriler ışığında öğreticilerin süreç içerisinde "okuma-anlama" becerisinin geliştirilebildiği algısına sahip oldukları görülmektedir. Bu sonuç, 5. problem başlı̆̆ında sunulan 'öğreticilerin \%48.3'ünün 'okuma-anlama' becerisinin diğer becerilere kıyasla en üst seviyede gerçekleştirilebildiği” tespiti ile de paralellik göstermektedir.

\footnotetext{
RumeliDE Dil ve Edebiyat Araștırmalar Dergisi Osmanağa Mahallesi, Mürver Ciçĕ́i Sokak, No:14/8 Kadıköy - ISTANBUL / TÜRKIYE 34714 e-posta: editor@rumelide.com tel: +90 $5057958124,+902167730616$

Address

RumeliDE Journal of Language and Literature Studies

Osmanağa Mahallesi, Mürver Çiçeği Sokak, No:14/8

Kadıköy - ISTANBUL / TURKEY 34714

e-mail: editor@rumelide.com,

phone: +90 $5057958124,+90216773$ o 616
} 
Evaluation of Basic Skills' achievements in the Process of Teaching Turkish Language to Foreigners through Online (Distance) Education on Educators' Perspective / Y. Yurdakul; G. B. Duman (pp. 153-186)

2a Alt Problem: Uzaktan eğitimle Türkçenin yabancı dil olarak öğretimi sürecinde “okuma-anlama” becerisinin geliştirilebilmesi “öğreticinin mesleki tecrübesine” göre değişkenlik göstermekte midir?

Şekil 2a: Mesleki tecrübe değişkenine göre

\begin{tabular}{|c|c|c|c|c|c|c|c|c|c|c|}
\hline \multirow{5}{*}{\multicolumn{2}{|c|}{$\begin{array}{r}10 \text { Yıl Üzeri } \\
6-10 \text { Yıl } \\
1-5 \text { Yıl } \\
\text { TÜM ÖĞRETicilLER }\end{array}$}} & \multicolumn{9}{|c|}{+2} \\
\hline & & \multicolumn{9}{|c|}{ 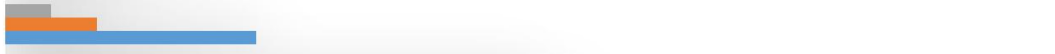 } \\
\hline & & \multicolumn{9}{|c|}{ 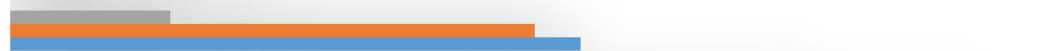 } \\
\hline & & \multicolumn{9}{|c|}{ 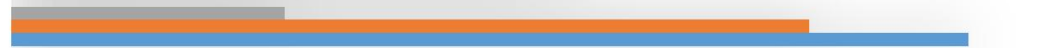 } \\
\hline & & 5 & 10 & 15 & 20 & 25 & 30 & 35 & 40 & 45 \\
\hline & TÜM Ö & ĞRETICILER & & -5 Y & & & & & 0 Yıl Üzeri & \\
\hline - Hayır & & 12 & & 7 & & & & & 3 & \\
\hline Kısmen & & 35 & & 23 & & & & & 8 & \\
\hline$\square$ Evet & & 42 & & 25 & & & & & 6 & \\
\hline
\end{tabular}

UETYÖ sürecinde "okuma-anlama" becerisinin geliştirilebilmesi bakımından mesleki tecrübe değişkenine göre öğretici görüssleri değerlendirildiğinde şu veriler ortaya çlkmaktadır: "hayır" ifadesi A grubunda \%12.7, B grubunda \%11.7, C grubunda \%17.6; "kısmen" ifadesi A grubunda \%41.8, B grubunda \%23.5, C grubunda \%47; "evet" ifadesi ise A grubunda \%45.4, B grubunda \%64.7, C grubunda \%35.3 oranındadır. "Hayır" görüşü tüm gruplarda en az yüzdelik orana sahiptir. Mesleki tecrübe değişkenine göre süreç içerisinde "okuma-anlama" becerisinin geliştirilemediğine yönelik bir algının olmadığı söylenebilir. A ve B gruplarında "evet” cevabının ağırlıkta olduğu görülür. B grubunda becerinin kazandırıldığına yönelik algı net biçimde yükselirken C grubunda "kısmen" görüşü ağırlık kazanmaktadır.

2b. Alt Problem: Uzaktan eğitimle Türkçenin yabancı dil olarak öğretimi sürecinde “okuma-anlama” becerisinin geliştirilebilmesi "öğreticinin eğitim seviyesine” göre değişkenlik göstermekte midir?

Şekil 2b: Eğitim seviyesi değişkenine göre

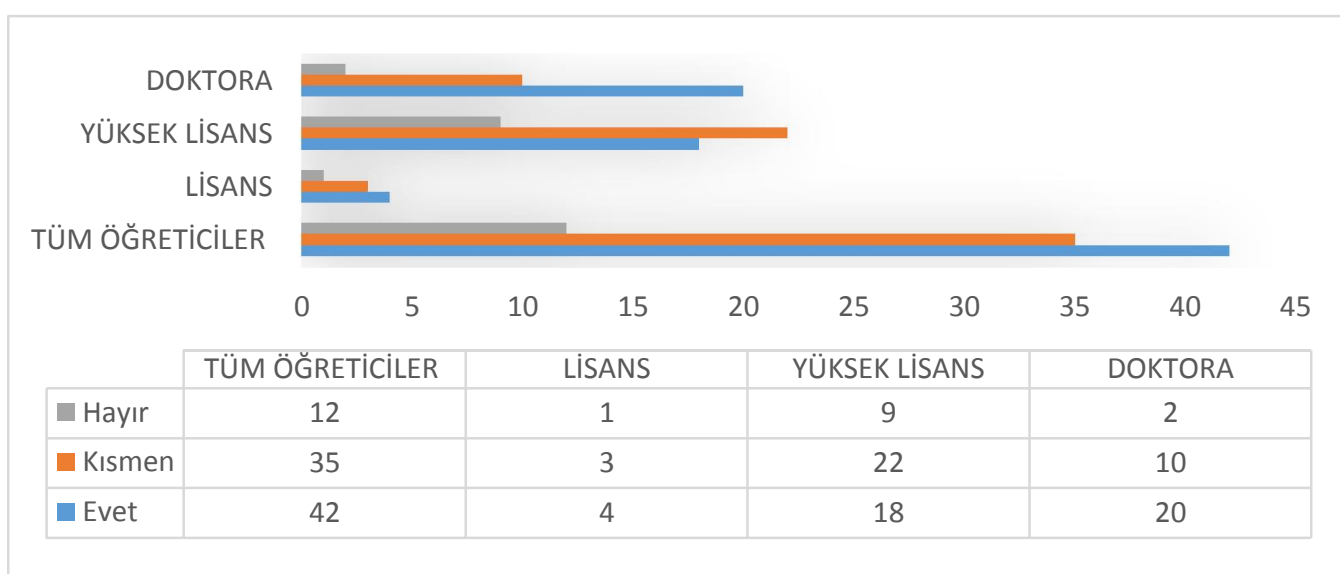


UETYÖ sürecinde "okuma-anlama" becerisinin geliştirilebilmesi bakımından "eğitim seviyesi" değişkenine göre öğretici görüşleri değerlendirildiğinde "hayır” ifadesi L grubunda \%12.5, YL grubunda \%18.3, DR grubunda \%6.2; "kısmen" ifadesi L grubunda \%37.5, YL grubunda \%44.9, DR grubunda \%31.2; "evet" ifadesi ise L grubunda \%50, YL grubunda \%36.7, DR grubunda \%62.5 oranındadır. Bu verilere göre "hayır" görüşü tüm gruplarda en az yüzdelik orana sahiptir. YL grubu, "kısmen" oranının yüksek oluşu ile diğer gruplardan ayrışmaktadır. L ve DR gruplarında "evet" algısının ağırlıkta olduğu, DR grubunun uzaktan eğitim sürecinde "okuma-anlama" becerisinin kazandırıldığından emin bir tutum sergilediği görülür. Sonuç olarak öğreticilerin "eğitim seviyesi”nin yükselmesi ile becerinin kazandırılması arasında belirgin bir bağıntı olduğu söylenemez.

\section{Problem: Uzaktan eğitimle Türkçenin yabancı dil olarak öğretimi sürecinde "konuşma" becerisinin yeterince geliştirilebildiğini düşünüyor musunuz?}

Dil edinim sürecinde "dinleme-anlama"nın gelişiminden sonra ortaya çıkan beceri, "konuşma" becerisidir (Memiş ve Erdem, 2013, s.303) Bu yönüyle dil becerileri arasında her zaman en önemli beceri olarak ele alınmaktadır (İşisă̆ ve Demirel, 2010, s.193) Çünkü süreç içerisinde alıcının edilgen olduğu dinleme safhasından geçerek dili kullanmada etkinleştiği dönemdir. Dilin kullanım yoğunluğu, becerinin gelişmesinde başat rol oynar. Ancak uzaktan eğitim sürecinde öğrencilerin yeteri kadar konuşabilme firsatı bulamadı̆̆ı, ders saati ile sınırlı kalan bir etkileşime sahip oldukları ifade edilebilir. Mete ve Gürsoy'un (2013) da dile getirdiği gibi, dil eğitiminin ana dilin konuşulduğu yerde yapılıp yapılmaması önemli farklar yaratmaktadır. Dil öğretimindeki öğrenen-öğreten-toplum ilişkisinde bir boyutun eksik kalması sebebiyle yurt dışında yabancı dil olarak Türkçe öğreten öğreticinin daha fazla desteğe ihtiyacı olmaktadır. Mete ve Gürsoy'un tespitine paralel olarak ifade edilmesi gereken durum, içinde bulunulan süreçte hem yurt içinde hem yurt dışında yabancı dil olarak Türkçenin öğretiminin "toplum" ayağı olmadan, uzaktan eğitim yoluyla yapılıyor olduğu gerçeğidir.

UETYÖ sürecinde "konuşma" becerisinin geliştirilebilmesi bakımından öğretici görüşleri Şekil 3a ve 3b’ye göre değerlendirildiğinde "hayır" \%33.7, "kısmen" \%29.2 ve "evet" 37.7 oranına sahiptir. "evet" ve "hayır" algılarının birbirine yakın yüzdelik dilimlerde olması değerlendirildiğinde iletişim kurabilmek bağlamında en önemli beceri olarak ifade edilen "konuşma" becerisinin, öğreticilerin görüşlerine göre istenen ölçüde gerçekleştirilemediği anlaşılmaktadır.

Eş zamanlı uzaktan eğitimde konuşma becerisinin kazandırılması, büyük oranda öğreticinin organize ettiği eğitim ortamına bağlı olmakla birlikte, bu beceri doğası gereği diyalog kurmayı gerektirir. Pandemi sürecinde hedef dilin konuşulduğu "toplum" ortamının tümüyle dışında bir eğitim gerçekleştiriliyor oluşu "konuşma" becerisinin kazandırılması ve geliştirilmesinde fark yaratan asıl unsur olarak değerlendirilebilir.

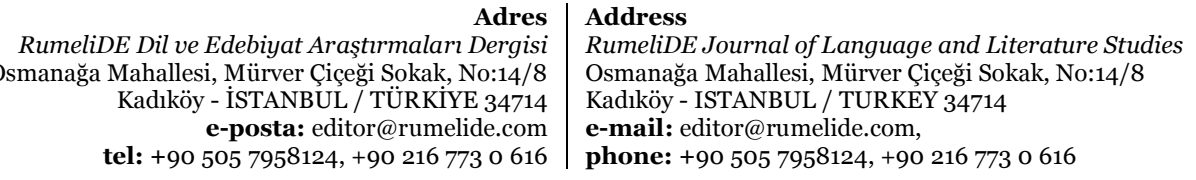

RumeliDE Dil ve Edebiyat Araştırmaları Dergisi Mürver Çiçegi Sokak, No:14/8 e-posta: editor@rumelide.com tel: +90 $5057958124,+902167730616$
Address

Osmană̌

e-mail: editor@rumelide.com,

phone: +90 5057958124 , +90 2167730616 
Evaluation of Basic Skills' achievements in the Process of Teaching Turkish Language to Foreigners through Online (Distance) Education on Educators' Perspective / Y. Yurdakul; G. B. Duman (pp. 153-186)

\section{3a. Alt Problem: Uzaktan eğitimle Türkçenin yabancı dil olarak öğretimi sürecinde "konuşma” becerisinin geliştirilebilmesi “öğreticinin mesleki tecrübesi”ne göre değişkenlik göstermekte midir?}

Şekil 3a: Mesleki tecrübe değişkenine göre

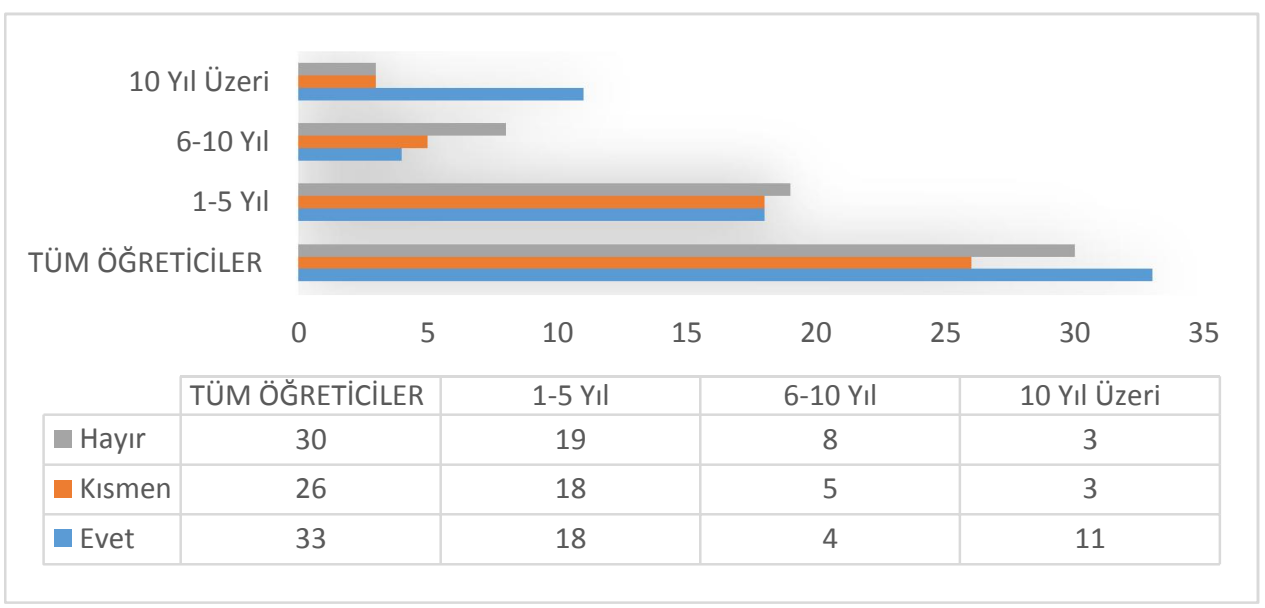

UETYÖ sürecinde "konuşma" becerisinin geliştirilebilmesi bakımından mesleki tecrübe değişkenine göre öğretici görüşleri değerlendirildiğinde "hayı" ifadesi A grubunda \%34.5, B grubunda \%47, C grubunda \%17.6; "kısmen" ifadesi A grubunda \%32.7, B grubunda \%29.4, C grubunda \%17.6; "evet" ifadesi ise A grubunda \%32.7, B grubunda \%23.5, C grubunda \%64.7 oranındadır. Süreç "konuşma" becerisinin geliştirilebilmesi bakımından değerlendirildiğinde B grubu belirgin biçimde "olumsuz", C grubu ise net olarak "olumlu" bir algıya sahiptir. A grubunda becerinin gerçekleştirilebilmesi noktasında olumlu ya da olumsuz bir ayrışma görülmemektedir. Ortaya çıkan durum, "konuşma" becerisinin karmaşık bir beceri oluşu ve davranış hâline getirilmesinde üst düzey öğretici tecrübesinin uzaktan eğitim süreci içerisinde etkili olduğu yönünde değerlendirilebilir.

\section{3b. Alt Problem: Uzaktan eğitimle Türkçenin yabancı dil olarak öğretimi sürecinde "konuşma" becerisinin geliştirilebilmesi "öğreticinin eğitim seviyesi”ne göre değişkenlik göstermekte midir?}

Şekil 3b: Eğitim seviyesi değişkenine göre

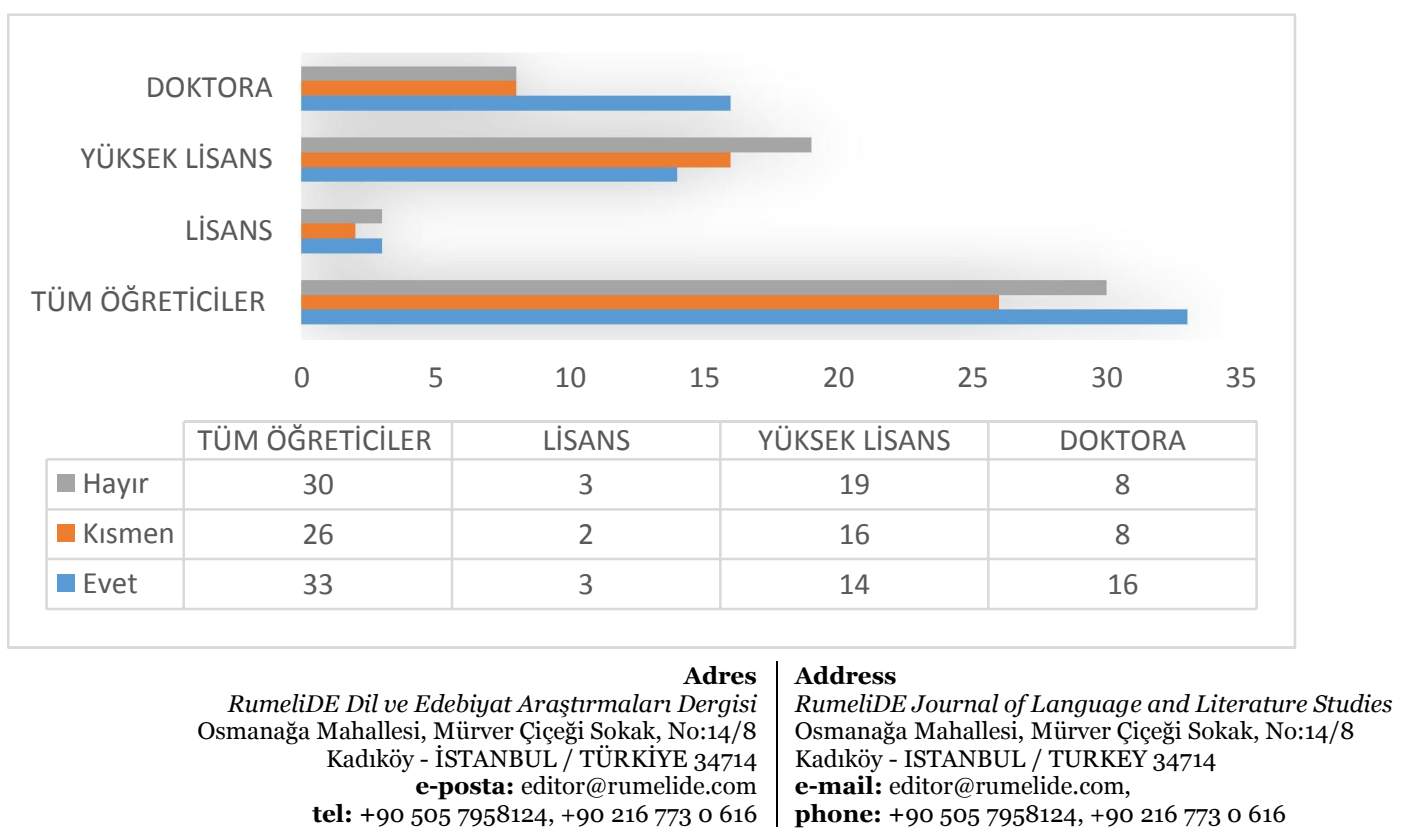


UETYÖ sürecinde "konuşma" becerisinin geliştirilebilmesi bakımından "eğitim seviyesi” değişkenine göre öğretici görüşleri değerlendirildiğinde "hayır" ifadesi L grubunda \%37.5, YL grubunda \%38.7, DR grubunda \%25; "kismen" ifadesi L grubunda \%25, YL grubunda \%32.6, DR grubunda \%25; "evet" ifadesi ise L grubunda \%37.5, YL grubunda \%28.5, DR grubunda \%50 oranındadır. L ve YL gruplarının belirgin bir algıya sahip olmadıkları görülmektedir. Bu veriler, DR grubunun "konuşma" becerisinin gerçekleştirilişi bakımından süreci daha olumlu algıladığını göstermektedir.

\section{Problem: Uzaktan eğitimle Türkçenin yabancı dil olarak öğretimi sürecinde "yazma" becerisinin yeterince geliştirilebildiğini düşünüyor musunuz?}

Doğal dil öğrenim ve öğretim sürecinin temel bilişsel becerilerin gerçekleşmesi bakımından son safhası "yazma" becerisidir. Dinleyen, konuşan, okuyan birey; son olarak yazabilen bir birey hâline gelir. Ancak Türkçenin yabancı dil olarak öğretilmesi sürecinde hedef kitlenin bilişsel yeterliliği paralelinde diğer beceriler ile birlikte geliştirilmesi hedeflenmektedir ve dil becerilerinin eşit şekilde geliştirilmiş olması dile hâkim olmanın gereğidir. Oysa Kalfa'ya (2014) göre Türkçenin yabancı dil olarak öğretiminde yazma becerilerini geliştirmeye yönelik çağdaş öğretim yöntem ve teknikleri yerine geleneksel yöntem ve tekniklerin kullanıldığı, böylece diğer becerilere göre bu becerinin geri plana atıldığı görülmektedir. Bu durum Türkçe öğrenen yabancıların yazma becerilerinin temel seviyeden itibaren diğer becerilere göre daha yavaş gelişmesine neden olmaktadır.

UETYÖ sürecinde "yazma" becerisinin geliştirilebilmesi bakımından Şekil 4a ve 4b’ye göre öğretici görüşleri değerlendirildiğinde, öğreticiler \%44.9 oranında "hayır", \%38.2i "kısmen” görüşünde iken "evet” diyenlerin oranı \%16.8’e düşmektedir. Bu çalışmada öğretici görüşleri neticesinde ortaya çıkan durum "yazma” becerisinin geliştirilmesinde güçlük çekildiğini doğrular niteliktedir.

4a. Alt Problem: Uzaktan eğitimle Türkçenin yabancı dil olarak öğretimi sürecinde “yazma” becerisinin geliştirilebilmesi “öğreticinin mesleki tecrübesi”ne göre değişkenlik göstermekte midir?

Şekil 4a: Mesleki tecrübe değişkenine göre

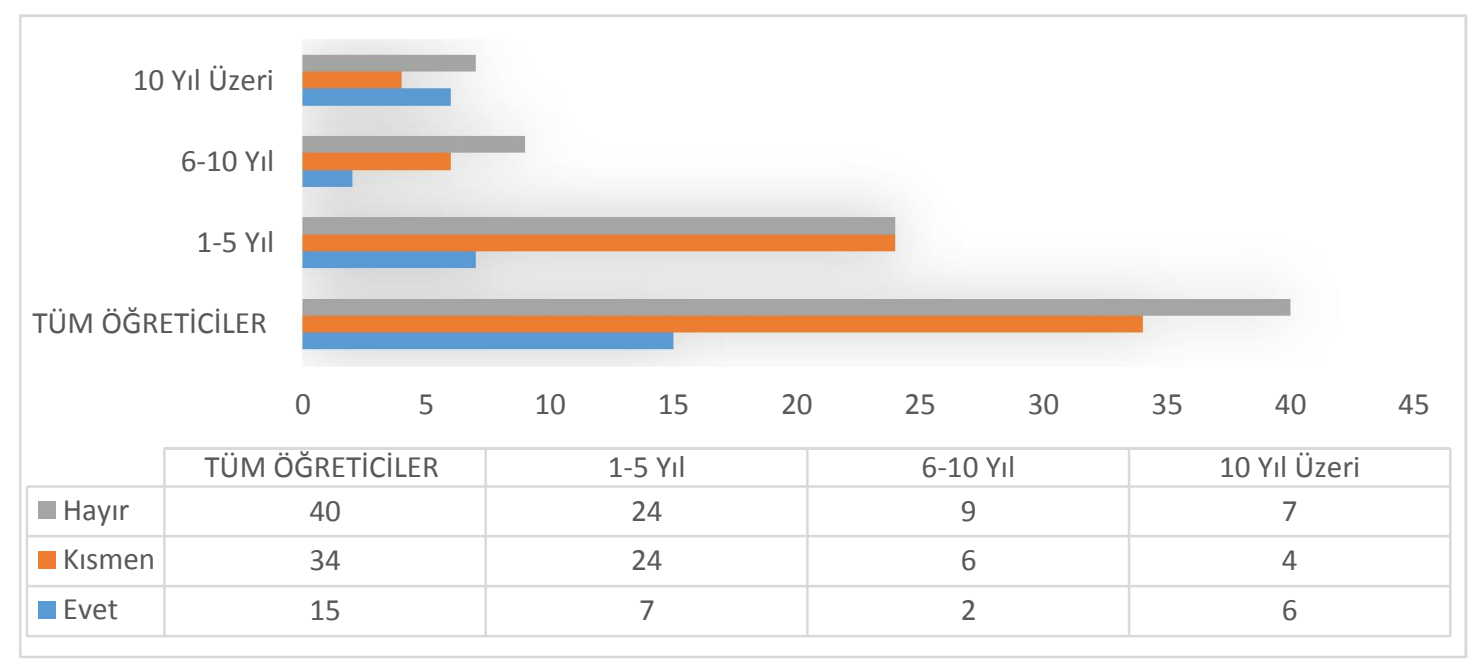

UETYÖ sürecinde "yazma" becerisinin geliştirilebilmesi bakımından mesleki tecrübe değişkenine göre öğretici görüşleri değerlendirildiğinde "hayır" ifadesi A grubunda \%43.6, B grubunda \%52.9, C

\begin{tabular}{r|l} 
Adres & Address \\
RumeliDE Dil ve Edebiyat Araştırmalar Dergisi & RumeliDE Journal of Language and Literature Studies \\
Osmanağa Mahallesi, Mürver Çiçeği Sokak, No:14/8 & Osmanağa Mahallesi, Mürver Çiçeği Sokak, No:14/8 \\
Kadıköy - İSTANBUL / TÜRKIYE 34714 & Kadık̈y - ISTANBUL / TURKEY 34714 \\
e-posta: editor@rumelide.com & e-mail: editor@rumelide.com, \\
tel: +90 505 7958124, +90 216773 o 616 & phone: +90 505 7958124, +90 2167730616
\end{tabular}


grubunda \%41.7; "kısmen" ifadesi A grubunda \%43.6, B grubunda \%35.2, C grubunda \%23.5; "evet" ifadesi ise A grubunda \%12.7, B grubunda \%11.7, C grubunda \%35.2 oranındadır. Mesleki tecrübenin

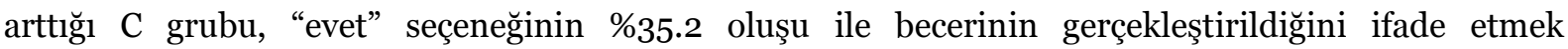
bakımından diğer gruplardan ayrışsa da "yazma" becerisinin geliştirilebilmesi ile mesleki tecrübe değişkeni arasında anlamlı bir bağıntı olduğu söylenemez.

\section{4b. Alt Problem: Uzaktan eğitimle Türkçenin yabancı dil olarak öğretimi sürecinde "yazma” becerisinin geliştirilebilmesi "öğreticinin eğitim seviyesi”ne göre değişkenlik göstermekte midir?}

Şekil 4b: Eğitim seviyesi değişkenine göre

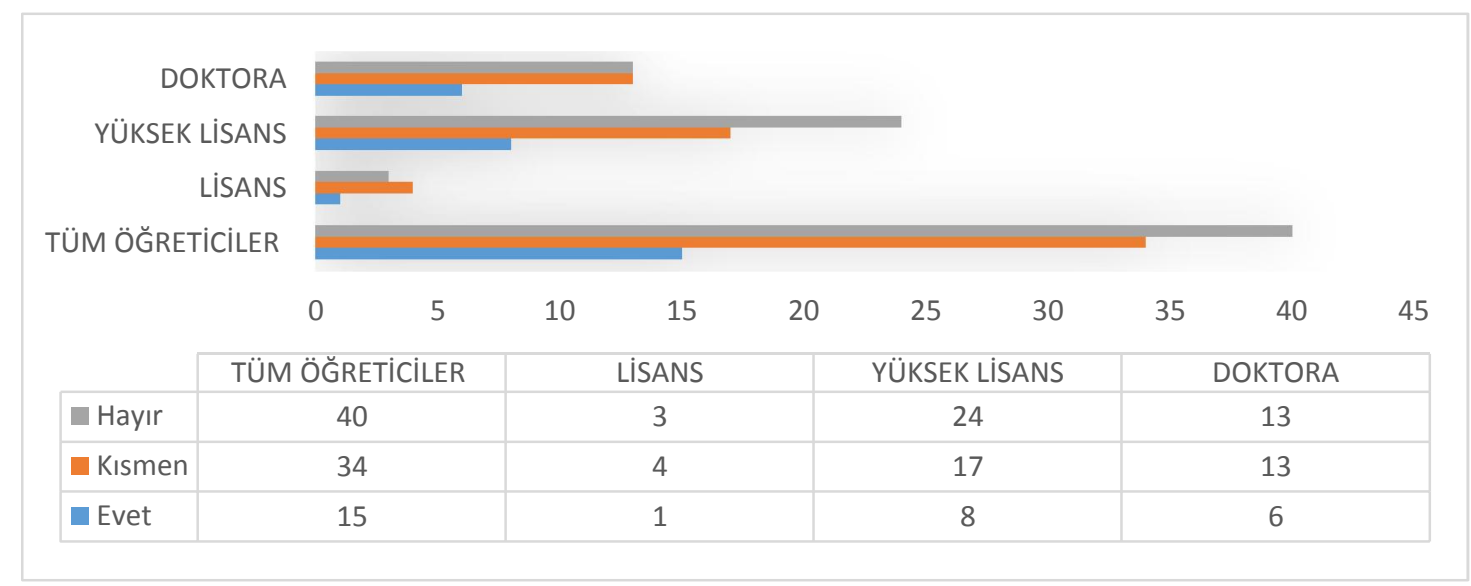

UETYÖ sürecinde "yazma” becerisinin geliştirilebilmesi bakımından öğretici görüşleri Şekil 4b’ye göre mesleki tecrübe değişkeni bakımından değerlendirildiğinde "hayır" ifadesi L grubunda \%37.5, YL grubunda \%48.9, DR grubunda \%40.6; "kısmen" ifadesi L grubunda \%50, YL grubunda \%34.6, DR grubunda \%40.6; "evet" ifadesi ise L grubunda \%12.5, YL grubunda \%16.3, DR grubunda \%18.7 oranındadır. Veriler ışığında "yazma" becerisinin gerçekleştirilebilmesinde, öğreticinin "eğitim seviyesi” değişkenine göre anlamlı bir değişim bulunmadığı; grupların bu becerinin süreç içerisinde beklenen düzeyde gerçekleştirilemediğine dair görüş beyan etttikleri ifade edilebilir.

\section{Problem: Uzaktan eğitimle Türkçenin yabancı dil olarak öğretiminin en başarılı olduğu beceri hangisidir?}

Öğreticilerden uzaktan eğitimle yabancı dil olarak Türkçe öğretimi sürecinde "dinleme-anlama, okuma-anlama, konuşma, yazma" temel dil becerilerinden hangisinin en iyi ölçüde geliştirilebildiği ile ilgili görüşlerini ifade etmeleri istenmiştir. Dönütler çerçevesinde oluşturulan Şekil 5a ve 5b’ye göre öğreticilerin \%1.1’i “yazma”, \%20.2'si “konuşma”, \%30.3’ü “dinleme-anlama” ve \%48.3’ü "okumaanlama" becerisinin diğer becerilere kıyasla en üst seviyede gerçekleştirilebildiği algısına sahiptir. Veriler ışığında UETYÖ alanının en başarılı olduğu temel beceri "okuma-anlama" becerisidir. Bu sonuç, 2. problem başlığında ortaya konan "öğreticilerin \%47.1 oranında "okuma-anlama" becerisinin gerçekleştirilebildiği algısına sahip oldukları çıkarımı ile de paralellik göstermektedir. 

görüşleri üzerinden değerlendirilmesi / Y. Yurdakul; G. B. Duman (167-186. s.)

5a. Alt Problem: Uzaktan eğitimle Türkçenin yabancı dil olarak öğretiminin en başarılı olduğu beceri, öğreticinin mesleki tecrübesine göre değişkenlik göstermekte midir?

Şekil 5a: Mesleki tecrübe değişkenine göre

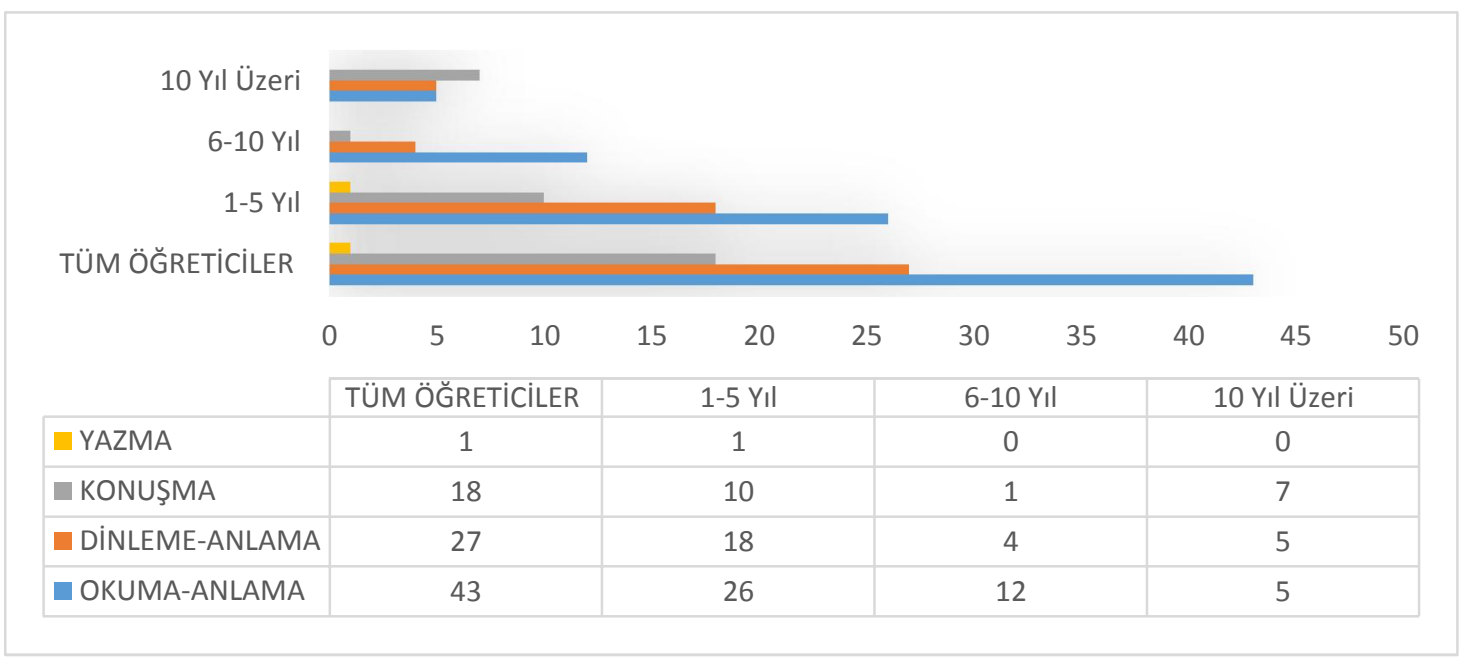

UETYÖ’nün en başarılı olduğu beceri, öğreticinin mesleki tecrübesine göre değerlendirildiğinde "yazma" becerisi A grubunda \%1.8, B grubunda \%o, C grubunda \%o; "konuşma” becerisi A grubunda \%18.1, B grubunda \%5.8, C grubunda \%41; "dinleme-anlama" becerisi A grubunda \%32.7, B grubunda \%23.5, C grubunda \%29.4; "okuma-anlama” becerisi ise A grubunda \%47.2, B grubunda \%70.5, C grubunda \%29.4 oranındadır. Buna göre UETYÖ’nün en başarılı olduğu beceri, A grubunda \%47.2 ve B grubunda \%70.5 oranında "okuma-anlama" iken; C grubunda \%41.1 ile "konuşma" becerisidir. Kazandırılmasında en başarılı olunan beceri ile öğretici tecrübesi değişkeni arasında anlamlı bir bağıntı görülmektedir. Öğretici tecrübesinin yükseldiği $\mathrm{C}$ grubunda, diğer becerilere kıyasla daha karmaşık bir beceri olan "konuşma” becerisinin gerçekleştirilebildiği algısı ağır basmaktadır.

\section{5b. Alt Problem: Uzaktan eğitimle Türkçenin yabancı dil olarak öğretiminin en başarılı olduğu beceri, “öğreticinin eğitim seviyesi”ne göre değişkenlik göstermekte midir?}

Şekil 5b: Eğitim seviyesi değişkenine göre

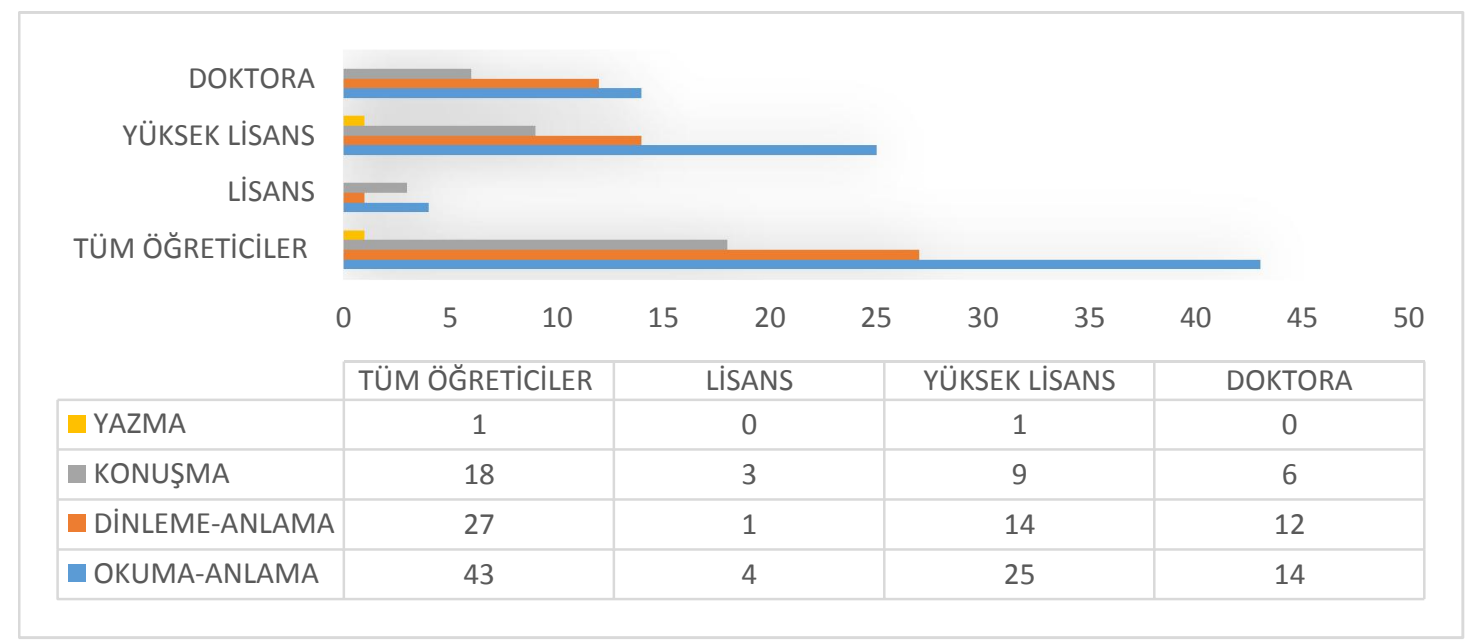


Evaluation of Basic Skills' achievements in the Process of Teaching Turkish Language to Foreigners through Online (Distance) Education on Educators' Perspective / Y. Yurdakul; G. B. Duman (pp. 153-186)

UETYÖ’nün en başarılı olduğu beceri, öğreticinin "eğitim seviyesi” değişkenine göre değerlendirildiğinde "yazma" becerisi L grubunda \%o, YL grubunda \%2, DR grubunda \%o; "konuşma" becerisi L grubunda \%37.5, YL grubunda \%18.3, DR grubunda \%18.7; "dinleme-anlama" becerisi L grubunda \%12.5, YL grubunda \%28.5, DR grubunda \%37.5; "okuma-anlama” becerisi ise L grubunda \%50, YL grubunda \%51, DR grubunda \%43.7 oranındadır. Şekil 5b’nin verilerine göre UETYÖ’de en başarılı olunan alanın "okuma" becerisi olduğu ifade edilmiştir. Öğretici algısı "eğitim seviyesi" değişkenine göre anlamlı bir farklılık göstermemektedir.

\section{Problem: Uzaktan eğitimle Türkçenin yabancı dil olarak öğretiminin en başarısız olduğu beceri hangisidir?}

Öğreticilerden uzaktan eğitimle yabancı dil olarak Türkçe öğretimi sürecinde "dinleme-anlama, okuma-anlama, konuşma, yazma" temel dil becerilerinden hangisinin geliştirilmesinde en başarısız olunduğu ile ilgili görüşlerini ifade etmeleri istenmiştir. Dönütler çerçevesinde oluşturulan Şekil 6a ve 6b’ye göre UETYÖ alanının en başarısız olduğu temel beceri \%53.9 oran ile "yazma" becerisidir. "yazma" becerisini \%30.3 ile "konuşma", \%11.2 ile "dinleme" ve \%4.5 oranı ile "okuma" becerisi takip etmektedir.

\section{6a. Alt Problem: Uzaktan eğitimle Türkçenin yabancı dil olarak öğretiminin en başarısız olduğu beceri, öğreticinin mesleki tecrübesine göre değişkenlik göstermekte midir?}

Şekil 6a: Mesleki tecrübe değişkenine göre

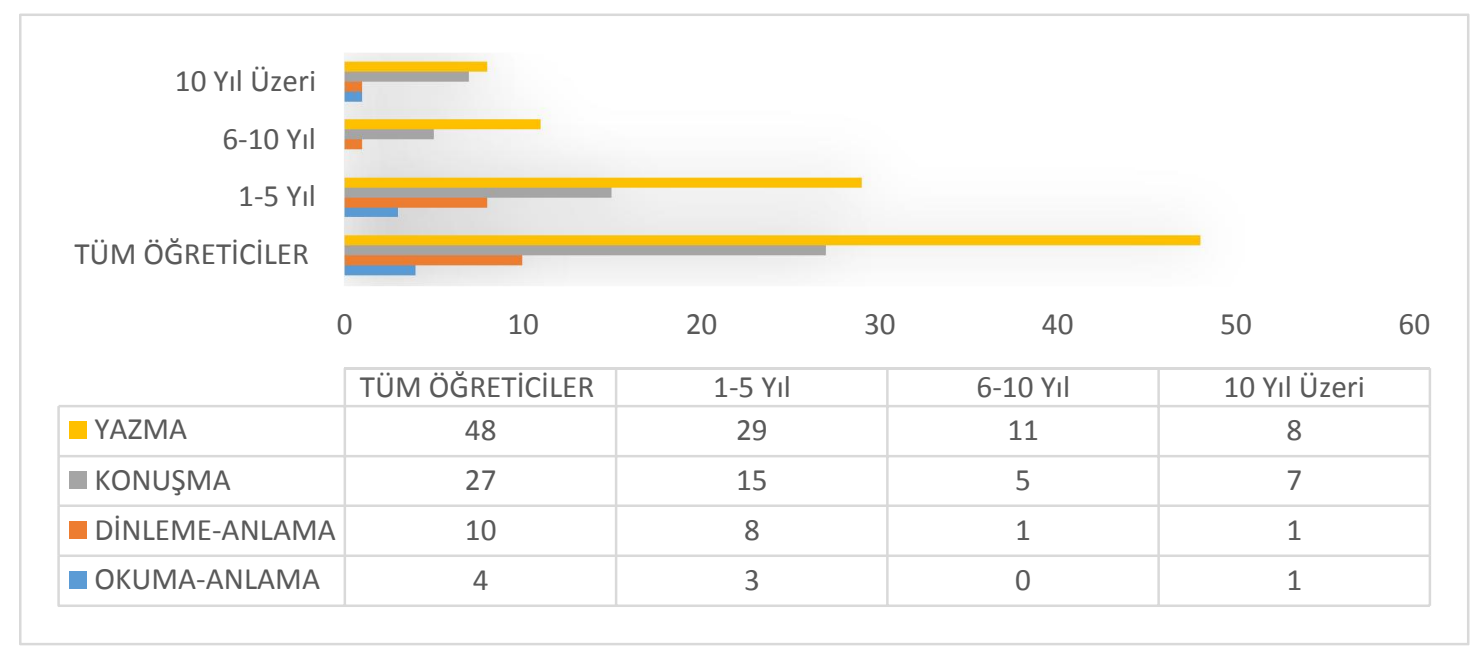

UETYÖ’nün en başarısız olduğu beceri, öğreticinin mesleki tecrübesine göre değerlendirildiğinde "yazma" becerisi A grubunda \%52.7, B grubunda \%64.7, C grubunda \%47; "konuşma" becerisi A grubunda \%27.2, B grubunda \%29.4, C grubunda \%41.1; "dinleme-anlama" becerisi A grubunda \%14.5, B grubunda \%5.8, C grubunda \%5.8; "okuma-anlama” becerisi ise A grubunda \%5.4, B grubunda \%o, C grubunda \%5.8 oranındadır. Şekil 6a'nın verilerine göre kazandırılmasında en başarısız olunan alanın tüm gruplarda "yazma" becerisi olduğu görülür. Ayrıca bu alt problemde, $\mathrm{C}$ grubu en başarısız olunan alan olarak \%41.1 oranında "konuşma" becerisini de işaret etmektedir. C grubu, "yazma" ile "konuşma" becerilerinin birbirlerine yakın oranlarda başarısız görülmesi ile mesleki tecrübe değişkeninin ilgili tema üzerindeki etkisi bakımından diğer gruplardan ayrışmaktadır. 


\section{6b. Alt Problem: Uzaktan eğitimle Türkçenin yabancı dil olarak öğretiminin en başarısız olduğu beceri, “öğreticinin eğitim seviyesi”ne göre değişkenlik göstermekte midir?}

Şekil 6b: Eğitim seviyesi değişkenine göre

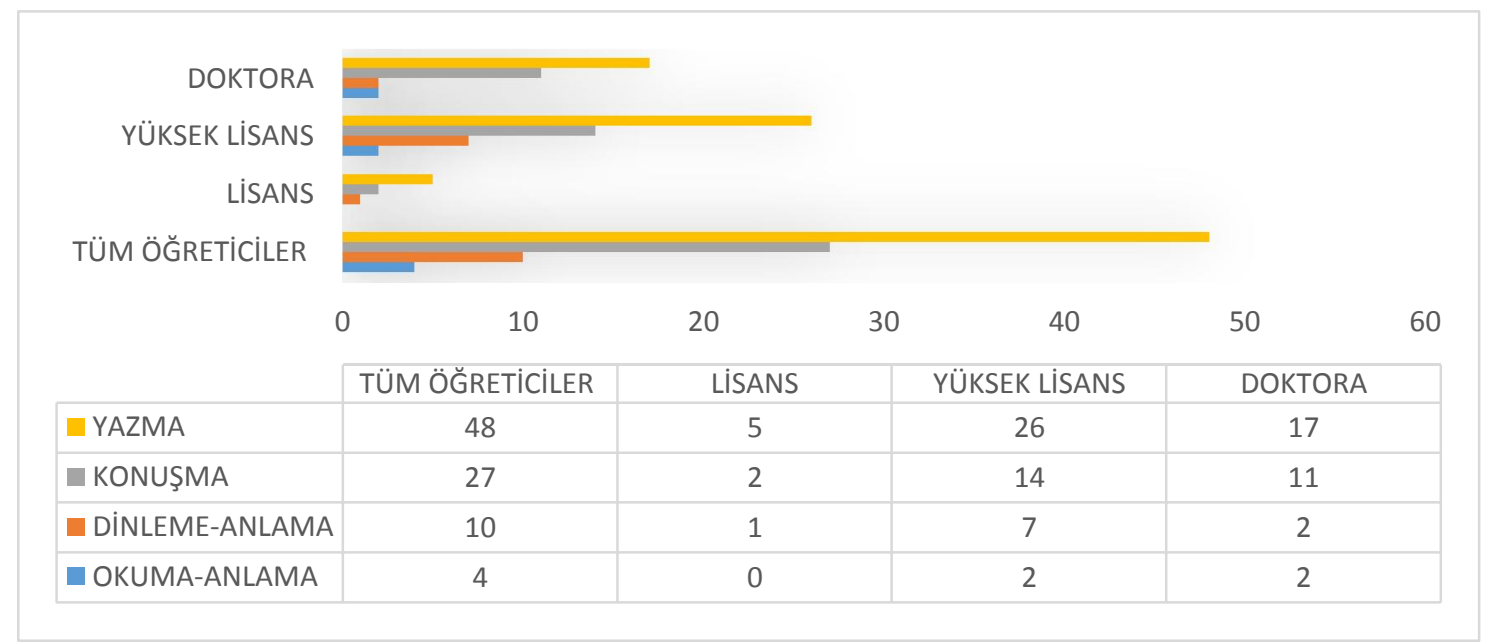

UETYÖ’nün en başarısız olunan becerisi, öğreticinin “eğitim seviyesi” değişkenine göre değerlendirildiğinde "yazma” becerisi L grubunda \%62.5, YL grubunda \%53, DR grubunda \%53.1; "konuşma" becerisi L grubunda \%25, YL grubunda \%28.5, DR grubunda \%34.3; "dinleme-anlama" becerisi L grubunda \%12.5, YL grubunda \%14.2, DR grubunda \%6.2; "okuma-anlama” becerisi ise L grubunda \%o, YL grubunda \%4, DR grubunda \%6.2 oranındadır. Şekil 6b’nin verilerine göre, gerçekleştirilmesinde en başarısız olunan becerinin L grubunda \%62.5, YL grubunda \%53 ve DR grubunda \%53.1 oranında "yazma" becerisi olduğu görülür. Bu bağlamda öğretici görüşlerinin "eğitim seviyesi” değişkenine göre belirgin biçimde farklılaşmadığı ifade edilebilir.

\section{Sonuçlar}

İlk örnekleri Cumhuriyetin ilk yıllarına kadar uzanan uzaktan eğitim çalışmalarının Türkçenin yabancı dil olarak öğretiminde uygulama sahası bulması 200o'li yılların başında görülür. İçinde bulunulan pandemi sürecine değin Türkçenin yabancı dil olarak öğretimi örgün eğitim kapsamında başta üniversiteler bünyesindeki TÖMER'ler olmak üzere kamu kurumları ve özel kurumlarda yüz yüze sınıf ortamlarında gerçekleştirilmekteydi. Dersler alana özgü fiziksel materyaller ile yürütülmekteyken bu derslerde uzaktan eğitim uygulamaları da eş zamansız metotla yardımcı bir görev üstlenmekteydi.

Covid-19 pandemisinin hayatın her alanında değişimi zorunlu kıldığı 2020 yılının başında Türkçenin yabancı dil olarak öğretimi, bütünüyle web ortamında ve eş zamanlı uzaktan eğitim metodunu benimsemiştir. Pandemi sürecinde Türkçenin yabancı dil olarak öğretimi; doğal dil ortamının dışında, eş zamanlı web derslerine özgü materyal yoksunluğu içerisinde yürütülmüştür. Öğreticilerin bu kısıtlllıklar içinde "dinleme-anlama, okuma-anlama, konuşma, yazma" becerileri yönüyle öğrencileri istendik düzeye getirebilmeleri için kişisel birikim ve yeteneklerini ön plana çıarmaları gerektiği görülmüş; öğreticinin "eğitim seviyesi” ve "mesleki tecrübesi”, temel değişkenler olarak ortaya çıkmıştır.

Yükseköğretimde alan uzmanı yetiştirmeye yönelik lisans bölümlerinin olmayışı sebebiyle öğreticilerin temel yeterliliklere, mesleklerini icra ettikleri süreç içerisinde sahip oldukları söylenebilir. Ancak

\begin{tabular}{r|l} 
Adres & Address \\
RumeliDE Dil ve Edebiyat Araştırmaları Dergisi & RumeliDE Journal of Language and Literature Studies \\
Osmanağa Mahallesi, Mürver Çiçeği Sokak, No:14/8 & Osmanağa Mahallesi, Mürver Çiçeği Sokak, No:14/8 \\
Kadıköy - İSTANBUL / TÜRKIYE 34714 & Kadıköy - ISTANBUL / TURKEY 34714 \\
e-posta: editor@rumelide.com & $\begin{array}{l}\text { e-mail: editor@rumelide.com, } \\
\text { phone: +90 505 7958124, +90 } 2167730616\end{array}$
\end{tabular}


Evaluation of Basic Skills' achievements in the Process of Teaching Turkish Language to Foreigners through Online (Distance) Education on Educators' Perspective / Y. Yurdakul; G. B. Duman (pp. 153-186)

araştırmaya katılan öğreticilerin \%6o’ının salgından önce uzaktan eş zamanlı eğitim tecrübesine sahip olmadığı, \%61.7'sinin ise henüz 1-5 yl arasında alan tecrübesine sahip olduğu görülmektedir. Bu deneyim eksikliğinin pandemi döneminin kendisine özgü kısıtllıkları içinde ortaya çıan sorunları çözmek bakımından öğreticilerin zorlanmalarına sebep olması ihtimal dâhilindedir.

Araştırmanın verilerine bakıldığında "dinleme-anlama" becerisinin gerçekleştirilebilme algısı A grubunda \%38.1, B grubunda \%41.1, C grubunda \%47'dir. Ayrıca "mesleki tecrübenin düşmesi” ile kararsızlık oranı yükselmektedir (Şekil 1a). Bu durum uzaktan öğretim sürecinde "mesleki tecrübe" ile "dinleme-anlama" becerisinin gerçekleştirilebilmesi arasında anlamlı bir bağıntı olduğunu göstermektedir.

UETYÖ sürecinde "konuşma" becerisinin geliştirilebilmesi bakımından öğretici görüşleri bütünüyle değerlendirildiğinde "hayır" \%33.7, "kısmen" \%29.2 ve "evet" 37.7 oranına sahiptir (3. Problem). Ancak mesleki tecrübenin en yüksek olduğu C grubu \%64.7 oranıla "konuşma" becerisini kazandırıldığı algısına sahiptir. Ortaya çıkan durum, "konuşma" becerisinin karmaşık bir beceri oluşu ve davranış hâline getirilmesinde üst düzey öğretici tecrübesinin uzaktan eğitim süreci içerisinde etkili olduğu yönünde değerlendirilebilir (Şekil 3a).

Ancak C grubu diğer beceriler ile kıyaslama yaparak "kazandırılmasında en başarısız olunan beceri" sorulduğunda \%47 oranında "yazma" becerisini ifade ederek diğer gruplarla ortaklaşmakta iken (Şekil 3a) \%41.1 oranında "konuşma" becerisinin kazandırılamadığını ifade etmesi ile de diğer gruplardan ayrışmaktadır (Şekil 6a).

Araştırmaya katılan öğreticilerin "eğitim seviyesi”ne bakıldığında ise lisans grubunun (L) \%8.9, yüksek lisans grubunun (YL) \%55, doktora grubunun (DR) \%35.9'luk bir ağırlığa sahip olduğu; öğreticilerin \%90.9 oranında lisansüstü eğitime sahip olduğu görülmektedir.

Araştırmanın verilerine bakıldığında "dinleme-anlama" becerisinin gerçekleştirilebildiği algısı L grubunda \%25, YL grubunda \%34.6, DR grubunda \%53.1 oranındadır (Şekil 1b). Buna göre "dinlemeanlama" becerisinin gerçekleştirilebilme algısı öğreticinin "eğitim seviyesi"nin yükselmesi ile paralel biçimde artmaktadır. "Eğitim seviyesi" değişkeninin etkili olduğu diğer bir beceri "okuma-anlama" becerisidir. Burada DR grubu diğer gruplara kıyasla olumlu ayrışmakta, becerinin kazandırıldığını \%62.5 oranı ile net biçimde ifade etmektedir. (Şekil 2b)

Araştırmaya katılan öğretici görüşlerinin tümü değerlendirildiğinde uzaktan eğitimle yabancı dil olarak Türkçe öğretiminde en başarılı olunan becerinin \%48.3 oran ile "okuma-anlama" becerisi olduğu (5. Problem) en başarısız olunan becerinin \%53.9 oran ile "yazma" becerisi olduğu görülür (6. Problem) Bilhassa derslerin kurs statüsünde yürütüldüğ̈̈ yurt dışı merkezlerde haftalık ders saatlerinin yer yer 1-4 saat aralığına düştüğü görülür. Bu tür süre kısıtlllıklarının yaşandığı ortamlarda dilbilgisi konularının hissettirilerek kavratılması ve yazma becerisine yönelik etkinliklerin uygulanması yeterli ölçüde gerçekleştirilememektedir.

Pandemi döneminde UETYÖ uygulamalarının gelişimi yanında öğreticinin mesleki tecrübesi ve eğitim seviyesi değişkenleri bakımından süreçle ilgili öğretici görüşlerini ele alan bu çalışma; sürecin başka alt problemler üzerinden genişletilmeye muhtaç olunduğunu da göstermektedir.

\begin{tabular}{|c|c|}
\hline & \\
\hline alarn $D$ & d Literatur \\
\hline $\mathrm{Mal}$ & Mahallesi, Mürver Çiçeği Sokak, No:14/8 \\
\hline Kadıköy & STANBUL / TURKEY 34714 \\
\hline $\begin{array}{r}\text { e-posta: edito } \\
\text { tel: }+905057958124,+\end{array}$ & $\begin{array}{l}\text { editor@rumelide.com, } \\
\text { +90 505 7958124, +90 } 216773 \text { o } 616\end{array}$ \\
\hline
\end{tabular}




\section{Öneriler:}

Zorunlu olarak yürütülen eş zamanlı uzaktan eğitim metodunun, pandeminin sona erdiği süreçte de uygulama sahası bulacağı düşünülebilir. Bu öngörüden hareketle eğitim-öğretim sürecinde karar verici konumunda olanlar, temel sorunları gidermeye yönelik girişimlerde bulunmalıdır.

UETYÖ alanında lisans bölümlerinde uzman yetiştirilmeyişi; sahada UETYÖ’nün uygulanmasını güçleştiren sebeplerdendir. Bu alanda lisansüstü programlarla gelişme sağlanmaya çalışllıyorsa da alan uzmanı yetiştirmeye yönelik lisans bölümleri açılmalıdır. Böylece öğretici temel yeterliliklerin lisansta edinilmesi ile sahada öğreticinin "mesleki tecrübesi” ve "eğitim seviyesi” değişkenlerinin etkisi azalacaktır.

Öğretici ve öğrenen arasında iletişimin kalitesini belirleyen temel unsurlardan biri "materyal"dir. Geleneksel yüz yüze öğretim uygulamaları ile eş zamanlı uzaktan eğitim modelinin ders içi ve ders dışı materyalleri farklılık göstermektedir. Eş zamanlı uzaktan eğitim sürecinin geleneksel materyaller ile sürdürülmek zorunda kalınması temel becerilerin gerçekleştirilmesinin önündeki en büyük engeldir. Becerilerin kazandırılması ile arasında bağıntı gördüğümüz öğreticinin "mesleki tecrübesi” ve "eğitim seviyesi”, materyal eksikliğinin yarattı̆̆ı olumsuzluğu bir ölçüde gideren değişkenler olarak göze çarpmaktadır. UETYÖ sürecinde temel becerilerin gerçekleştirilebilmesi için e-öğrenme ve m-öğrenme materyallerin kullanımı elzemdir. Bu materyaller kurumsal bazda üretilerek öğreticilerin ve öğrencilerin istifadesine sunulmalıdır.

Sanal sinıflarda öğrenen-öğreten-toplum ilişkisinin "toplum” boyutu eksik kalmaktadır. Bu sebeple "konuşma" becerisinde tam öğrenmenin sağlanabilmesi mümkün olamamaktadır. Eksik kalan doğal dil ortamının oluşmasına ve hedef dil ile eş zamanlı temas süresini artırmaya yardımcı olacak web tabanlı forumlar oluşturulmalıdır.

Covid-19 pandemisiyle zorunlu hâle dönüşen uzaktan eğitim süreci, bütünüyle eş zamanlı gerçekleştirilmektedir. Süreç içerisinde büyük özveri gösteren öğreticilerin her tür problemi deneyimlemek ve sorunu kendisi çözümlemek durumunda kaldığı görülmektedir. Alanda faaliyet gösteren öğreticiler arasında deneyimlerin aktarılacağı organizasyonlar kurulmalı, öğreticiler hizmet içi seminerler yolu ile eş zamanlı uzaktan eğitim modelinin tüm gereklerine hazır hâle getirilmelidir.

\section{Kaynakça}

Balaban, E. (2012). Dünyada ve Türkiye'de uzaktan eğitim ve bir proje önerisi. Işık Üniversitesi, İstanbul.

Bozkurt, A. (2017). Türkiye'de uzaktan eğitimin dünü, bugünü ve yarını. Auad. 3(2), 85-124.

Bozkurt, A. (2020). Koronavirüs (Covid-19) pandemi süreci ve pandemi sonrası dünyada eğitime yönelik değerlendirmeler: Yeni normal ve yeni eğitim paradigması. Auad, 6(3), 112-142.

Büyükaslan, A. (2007). Yabancı dil Türkçenin öğretilmesinde yeni yöntemler: bilisim uygulamaları, çözüm önerileri. Department D'études Turques Turcologue u-strasbourg, 3o(5), Strasbourg.

Duman, G. B. ve Yurdakul Y. (2021). Türkçenin yabancı dil olarak uzaktan öğretiminde öğreticilerin materyal kullanımı ve teknolojik alt yapıya yönelik tutum ve görüşleri. $Z f W T, 13(1), 419-438$, //DOI: 10.46291/ZfWT/130121

Eroğlu, F. ve Kalaycı, N. (2020). Üniversitelerdeki zorunlu ortak derslerden Türk dili dersinin uzaktan ve yüz yüze eğitim uygulamalarının karşlaş̧tırılarak değerlendirilmesi. Ana Dili Eğitimi Dergisi, $8(3), 1001-1027$.

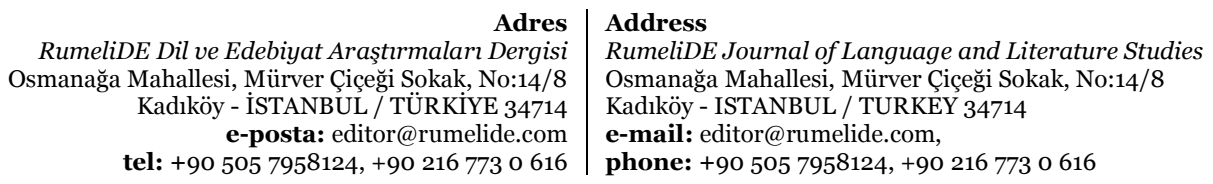


Evaluation of Basic Skills' achievements in the Process of Teaching Turkish Language to Foreigners through Online (Distance) Education on Educators' Perspective / Y. Yurdakul; G. B. Duman (pp. 153-186)

İşisağ, K., U. ve Demirel, Ö. (2010). Diller için avrupa ortak başvuru metni’nin konuşma becerisinin gelişiminde kullanılması. Eğitim ve Bilim, 190-204.

Kalfa, M. (2014). Yabancllara Türkçe öğretiminde temel düzeydeki öğrencilerin eğitsel oyunlarla yazma becerilerinin geliştirilmesi. Hacettepe Üniversitesi Türkiyat Araştırmaları Dergisi, $1(20), 85-102$

Kaya, Z., Erden, O., Çakır, H., Bağırsakçı, B., (2004). Uzaktan eğitimin temelleri dersindeki uzaktan eğitim ihtiyacı ünitesinin web tabanlı sunumunun hazırlanması. Turkish Online Journal of Educational Technology, 3(3), 165-175.

Kılıç, S., Horzum, M. B., ve Çakıroğlu, Ü. (2016). Çevrimiçi eş zamanlı öğrenme ortamlarında öğrencilerin öğretimsel, sosyal ve bilişsel buradallk algılarının belirlenmesi. 1. Turkish Journal of Computer and Mathematics Education, 7(2), 350-364.

Lorenz, E. N. (1972). Predictability: Does the flap of a butterfly's wings in Brazil set off a tornado in Texas? Paper presented at 139 th Annual Meeting of the American Association for the Advancement of Science, Washington DC, The US.

Memiş, M. ve Erdem, M., D. (2013). Yabancı dil öğretiminde kullanılan yöntemler, kullanım özellikleri ve eleştiriler. Turkish Studies, 8(9), 297- 318.

Melanlıŏlu, D. (2011). İlköğretim Türkçe öğretim programının "dinleme türleri” bakımından değerlendirilmesi. İnönü Üniversitesi Ĕ̆itim Fakültesi Dergisi, 12(3), 65-78.

Mete F., Gürsoy Ü. (2013). Yabancı dil olarak Türkçe öğretiminde öğretmen yeterliklerine ilişkin görüssler. Hacettepe Üniversitesi Eğitim Fakültesi Dergisi (H. U. Journal of Education), 28(3), 343-356.

Mutlu, M. E., Erorta, Ö. Ö., Kayabaş, B. K., Kayabaş, İ. (2014). Anadolu Üniversitesi Açıöğretim sisteminde e-öğrenmenin gelişimi. Ali Ekrem Özkul, Cengiz Hakan Aydın, Elif Toprak, Evrim Genç Kumtepe (Eds). Açıköğretimle 30 Yıl, 1-58 Eskiş̧ehir: Anadolu Üniversitesi Yayınları.

Odabaş, H., (2003). İnternet tabanlı uzaktan eğitim ve bilgi ve belge yönetimi bölümleri. Türk Kütüphaneciliği, 17(1), 22-36.

Özbay, M., Bahar, M. A. (2016). Türkçenin yabancı dil olarak öğretiminde uzmanlık sorunu. Aydın Tömer Dil Dergisi, 1(1), 1-29.

Pilancı, H. (2015). Web tabanlı uzaktan dil öğretimindeki gelişmeler ve yabancı dil olarak Türkçe öğretimi. International journal of languages education 1, 3(3), 253-253.

Taşer, S. (2012). Konuşma eğitimi. İstanbul: Pegasus.

Vandergrift, L. ve Goh, C. C. (2012). Teaching and learning second language listening: metacognition in action. New York: Routledge.

Yıldırım, A. ve Şimşek, H. (2018). Sosyal bilimlerde nitel araştırma yöntemleri. (11.baskı). Ankara: Seçkin.

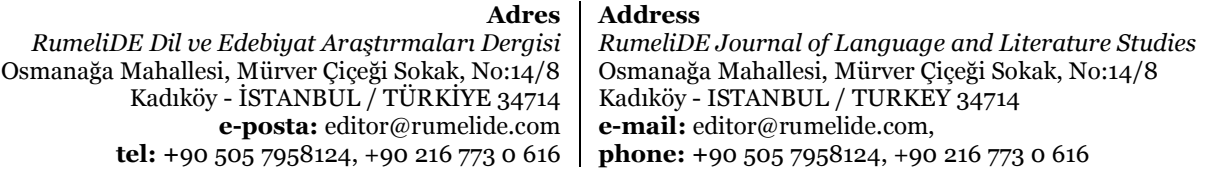

